JOB MARKET SIGNALING THROUGH OCCUPATIONAL LICENSING

Peter Q. Blair

Bobby W. Chung

WORKING PAPER 24791 
NBER WORKING PAPER SERIES

\title{
JOB MARKET SIGNALING THROUGH OCCUPATIONAL LICENSING
}

\author{
Peter Q. Blair \\ Bobby W. Chung \\ Working Paper 24791 \\ http://www.nber.org/papers/w24791 \\ NATIONAL BUREAU OF ECONOMIC RESEARCH \\ 1050 Massachusetts Avenue \\ Cambridge, MA 02138 \\ July 2018, Revised October 2022
}

We received helpful comments from: Kerwin Charles, William Spriggs, Morris Kleiner, Ed Timmons, Jennifer Doleac, Isaiah Andrews, David Autor, Ainhoa Aparicio, William Darity Jr., Patrick Bayer, Thummim Cho, David Deming, Michael Dinerstein, William Dougan, Steven Durlauf, Susan Dynarski, Robert Fleck, Michael Kofoed, Stefano Giglio, Edward Glaeser, Claudia Goldin, Sarena Goodman, Benjamin Hansen, Arnold Harberger, James Heckman, Nathaniel Hendren, Kirabo Jackson, Damon Jones, Lawrence Katz, Mark Klee, Glenn Loury, Alexandre Mas, Jonathan Meer, Conrad Miller, Richard Murnane, David Neumark, Oyebola Olabisi Okunogbe, Curtis Simon, Todd Sinai, Kent Smetters, Stan Veuger, Shing-Yi Wang, Matthew Weinzierl, Kyle Welch, Brian Jacob, several anonymous referees and many others. We also received helpful comments from the seminar participants at NBER Labor Studies Meeting, Harvard, Stanford (SITE Conference), Columbia, Cornell, Brown, Clemson, West Point Military Academy, Collegio Carlo Alberto, Bowdoin College, Federal Reserve Bank of Chicago, AEA Annual Meeting, Economic Demography Workshop, Southern Economic Association Conference, and the South Carolina Applied Micro Day Conference. We also thank Jennifer Moore, Brian Trainer, Andrew Mannheimer, Benjamin Posmanick, Elijah Neilson, Kenneth Whaley, Majid Hashemi, Mickey Whitzer, Jhacova Williams, Anne-Marie Korte, Morgan Adderley, and Rafael Luna (Scientific Storytelling) for help with the manuscript. All remaining errors are ours. Blair is grateful for generous research funding from the Upjohn Institute Early Career Research Award. The views expressed herein are those of the authors and do not necessarily reflect the views of the National Bureau of Economic Research.

NBER working papers are circulated for discussion and comment purposes. They have not been peer-reviewed or been subject to the review by the NBER Board of Directors that accompanies official NBER publications.

(C) 2018 by Peter Q. Blair and Bobby W. Chung. All rights reserved. Short sections of text, not to exceed two paragraphs, may be quoted without explicit permission provided that full credit, including (C) notice, is given to the source. 
Job Market Signaling through Occupational Licensing

Peter Q. Blair and Bobby W. Chung

NBER Working Paper No. 24791

July 2018, Revised October 2022

JEL No. D21,D82,D86,J24,J31,J70,K23,K31,L51

\begin{abstract}
Among men, the black-white wage gap is as large today as it was in 1950. We test whether the black-white wage gap is due to asymmetric information using newly collected data on occupational licensing laws that ban workers with criminal records. We find evidence supporting this hypothesis. The licensing premiums for black men are largest in licensed occupations that restrict felons - particularly in states with Banthe-Box laws and at small firms. In these contexts where a worker's criminal history is difficult to infer, we find that occupational licensing reduces asymmetric information and reduces the racial wage gap.
\end{abstract}

Peter Q. Blair

Harvard University

Graduate School of Education

407 Gutman Library

Cambridge, MA 02138

and NBER

peter_blair@gse.harvard.edu

Bobby W. Chung

Swan Business Center, Room 104D

St Bonaventure, New 14778

United States

bchung@sbu.edu

Website is available at www.peterqblair.com 


\section{Introduction}

Occupational licensing requirements affect 1 in 4 workers in the United States (Kleiner and Krueger, 2013; Gittleman et al., 2018). ${ }^{1}$ In occupations that have licensing requirements, it is illegal for an individual to work for pay without a license. Moreover, many occupational licenses preclude individuals with criminal records from obtaining a license. We study whether occupational licensing serves as a job market signal and a screening device, in an analogous manner to the role played by education in the Spence model (Spence, 1973).

Similar to the prediction of the Spence model of signaling, seminal economic models of statistical discrimination spotlight the importance of information in determining wages (Akerlof 1970; Phelps 1972; Arrow 1973; Coate and Loury 1993). Both theoretical frameworks imply that asymmetric information could result in education and wage inequality. ${ }^{2}$ Statistical discrimination by employers could lead to racial disparity in labor market outcomes in the presence of asymmetric information on worker traits which vary systemically by race and are correlated with productivity (De Tray, 1982; Altonji and Pierret, 2001; Pager, 2003; Goldsmith et al., 2006; Autor and Scarborough, 2008; Wozniak, 2015). Given the stark disparity in arrest rates between black and white men, asymmetric information about a worker's criminal history could lead employers to use race as the proxy of a worker's criminal past and subsequently the worker's productivity (Pager, 2003; Pager et al., 2009; Agan and Starr, 2018; Doleac and Hansen, 2020). ${ }^{3}$ In the spirit of the Spence model, when an occupational license has a felony restriction, it is more costly for black men to obtain a license (on average). The license conveys more information about their productivity, resulting in a larger license wage premium for black men

\footnotetext{
${ }^{1}$ Similarly, in the European Union $22 \%$ of workers report having an occupational license (Koumenta and Pagliero, 2018).

${ }^{2}$ When ability is privately known to workers and imperfectly observable to employers, firms may rely on demographic characteristics such as the race of an individual to infer the worker's productivity and wage.

${ }^{3}$ According to Chetty et al. (2020), black men born to parents in the bottom $1 \%$ of the income distribution are more than 3 times as likely to be incarcerated when compared to their white male peers.
} 
than white men, as shown theoretically in Blair and Chung (2021). In this paper, we test empirically whether occupational licensing reduces the racial wage gap among licensed workers by reducing asymmetric information about a worker's criminal history.

We study the link between racial wage gaps and occupational licensing for two reasons. First, Bayer and Charles (2018) documents that the black-white gap in earnings for men is as large today as it was in 1950. Is the racial wage gap in men's earnings due to a persistent market failure? Becker (1957) argued that taste-based discrimination would be competed away in the long-run. Second, in statistical discrimination models where racial gaps are not competed away, it is of interest whether the specific market failure explaining the racial wage gap in men's earnings is asymmetric information about a worker's criminal history, since occupational licensing could provide that information to the market (Phelps 1972; Arrow 1973).

To pinpoint variation in firms' perceptions of the criminal history of black men, we leverage state-level variation in occupational licensing laws that impose permanent mandatory bans on individuals with felonies. We construct this new data set using administrative law records from the Criminal Justice Section of the American Bar Association (ABA). We layer this variation in occupational licensing laws affecting felons with state-level variation in Ban-the-Box (BTB) legislation, which makes it illegal for firms to inquire about the criminal history of workers early in the hiring process (Doleac and Hansen, 2020). Firms in BTB states are restricted in their ability to deduce information about a worker's criminal history and therefore should find the licenses with felony restrictions more informative than similar firms in non-BTB states - and differentially for black men who are more at risk of having been incarcerated. Furthermore, we use variation in firm size to test for whether employers use information about the felony restrictions in licensing laws to screen black men on criminal history. Since small firms are less likely to have a human resources department to conduct background checks than large firms, small firms stand to gain more from the information about felony status that is bundled in occupational 
licenses.

For our analysis, we combine the unique administrative data about the felony restrictions of licensing from the ABA with self-reported data on worker licensure, demographic, and employment characteristics from the Survey of Income and Program Participation (SIPP). ${ }^{4}$ Our identification strategy utilizes state variation in license requirements to compare the wages of workers in the same occupation across states that vary in whether they require a license for the occupation and if conditional on requiring a license the license excludes felons. We find that black men earn a higher license wage premium than their white counterparts. The magnitude of the licensing premium for black men is large enough so that there is no wage gap between licensed black men and licensed white men even though unlicensed black men on average earn less than unlicensed white men. In alignment with our hypothesis that licensing reduces the racial wage gap among men because it lessens asymmetric information about a worker's criminal history, the largest license premiums for black men accrue in occupations with felony bans in BTB states, where non-felony status is harder for employers to deduce. Further, we present suggestive evidence that firms use licenses to screen for felony status. In small firms but not large firms, the license premium for black men increases in the presence of a permanent mandatory bans on felons. Our findings provide evidence that occupational licensing is an informative job market signal for black men that is used by firms to screen a worker's criminal history.

While there is evidence in the literature that licensing premiums estimated from crosssectional variation mirror estimates from quasi-random variation, we were cognizant that our results could be affected by selection on unobservables or measurement error (Pizzola and Tabarrok, 2017). ${ }^{5}$ First, we perform a balancing test and show that conditional on occupation, that there is limited selection on observables into any licensed occupation -

\footnotetext{
${ }^{4}$ We also find similar results using the Current Population Survey (CPS).

${ }^{5}$ Pizzola and Tabarrok (2017) analyze a de-licensing reform of funeral services in 1983 in Colorado. They find the estimate of the license premium from using this natural experiment is similar to the license premium obtained from using the cross-sectional variation in license requirements.
} 
and less selection on observables into licensed occupations with mandatory permanent bans on felons. Second, we use the sensitivity bias approach pioneered by Altonji et al. (2005) and Oster (2019) to test whether our main results are driven by selection on unobservables. We find that selection on unobservables would need to be implausibly large to explain our results when compared to related estimates in the literature (Kleiner and Krueger 2013; Nunn and Wantchekon 2011).

The second threat to identification in our study is measurement error in self-reported licensing attainment by survey respondents. This problem occurs in general with licensing data in nationally representative surveys (Gittleman et al., 2018). To address this problem, we follow Blair and Chung (2019) and collapse the variation in licensing from the individual level to the state-occupation level using a 50-50 rule. In our main analysis, a state-occupation pair is licensed if at least $50 \%$ of respondents in that state-occupation report having a license. We provide additional checks to show our results are robust to varying the threshold, using the administrative licensing data from the ABA to reduce false negatives in the self-reported licensing data, correcting bias in small state-occupation cells, and addressing potential misreporting of occupational affiliation. ${ }^{6}$

The analysis that we implement to address concerns about selection and measurement error, as well as a bevy of other sensitivity analysis, supports the reliability of our central finding that occupational licenses reduce the racial wage gap between black men and white men when they are informative about a worker's criminal history. This is not a normative statement about whether imposing occupational licensing requirements is good public policy but rather a positive statement about the impact of licensing laws on racial inequality. Whereas occupational licensing operates as a labor market friction, it provides information to the labor market that helps black men overcome another labor market friction - discrimination on the basis of race.

Our work relates to studies that investigate the role of statistical discrimination in

\footnotetext{
${ }^{6}$ We also show that our results similar when we use individual self-reports of license status.
} 
shaping racial inequality (De Tray, 1982; Holzer et al., 2006; Autor and Scarborough, 2008; Wozniak, 2015; Miller, 2017). The finding that an occupational license functions as a screening device for black men without criminal records mirrors the result in Arcidiacono et al. (2010), who show that black men with college degrees do not face a racial wage penalty relative to their white peers whereas black men with a high school diploma, or less, do. Occupational licenses that restrict felons in our study play the same wage equalizing and ability revelation role for black men as does college completion in their study. Moreover, our work complements the recent studies of the labor market impacts of Banthe-Box legislation by showing how the inclusion (rather than exclusion) of information about a worker's criminal history impacts labor market inequality (Shoag and Veuger 2021; Agan and Starr 2018; Craigie 2020; Doleac and Hansen 2020).

Our findings, moreover, contribute to the literature on measuring the licensing premium. We demonstrate the existence of heterogeneity in the licensing premium by race among men. Kleiner and Krueger (2010) and Kleiner and Krueger (2013) provided the first estimates of the average licensing premium using nationally representative data. The most recent estimate of the licensing premium, which is an average premium across both race and gender, is $4.8 \%$ (Gittleman et al., 2018). ${ }^{7}$ We contribute by differentiating the licensing premium by race among black and white men to find that the licensing premium for black men (16\%) is higher than the licensing premium for white men $(4 \%){ }^{8}$ This larger licensing premium for black men that we document is almost entirely driven by the licensing premium for black men working in licensed occupations with mandatory permanent bans on felons in BTB states.

Our work also builds on and updates an important historical literature on the labor market effects of occupational licensing by race. In a pioneering study focusing on 11 occupations during the Progressive Era, Law and Marks (2012) show that occupational

\footnotetext{
${ }^{7}$ This result in Table 4 (column 5) of Gittleman et al. (2018).

${ }^{8}$ In a related paper, Gomez et al. (2015) use Canadian data to show that immigrants earn a licensing premium that is 5 p.p. larger than Canadian citizens.
} 
licensing reduced employment of women and black workers in only 2 of the licensed occupations. In some cases, they found that women and black workers were more likely to be employed in an occupation following the introduction of a licensing statute. In our previous work that explores the employment effects of licensing by race using contemporary data from the CPS, we find licensing reduces employment, with white men experiencing larger negative employment impacts of licensing (Blair and Chung, 2019). Kleiner and Soltas (2019) using a different empirical strategy estimate a negative impact of licensing on employment of a similar magnitude. ${ }^{9}$

Our paper is laid out as follows: in Section 2, we describe how we create the data for our analysis and select our sample. In Section 3, we specify the empirical models that we use to estimate heterogeneity in the licensing premium by race and whether the license has a felony restriction. In Section 4, we describe our key result that the licensing premium is larger for black men than white men. In Section 5 and 6, we show that our key results are unlikely to be driven by selection issues or measurement error. In Section 7 , we show that our results are externally valid, using another nationally representative survey. In Section 8, we conclude.

\section{Licensing Data Construction and Sample Selection}

Our analysis relies on two main types of data: (i) occupational licensing requirements, which vary by state and occupation, and (ii) wage and demographic data from a nationally representative survey. We first describe how we use administrative data from the American Bar Association and a web-scrapping application to construct state-byoccupation variation in occupational licensing requirements that screen out felons. Next, we describe how we use the self-reported licensing status of individuals in the SIPP and

\footnotetext{
${ }^{9}$ Likewise Blair and Fisher (2021) find evidence for negative impacts of occupational licensing on employment and market clearing in a digital labor market. Exploiting recent policy changes, Chung et al. (2021) and Chung (2022) find more stringent license requirements reduce employment of preK-12 teachers and real estate agents.
} 
a threshold rule to generate state-by-occupation variation in all licensing laws, including those without felon restrictions. We then describe how we harmonize the two sources of licensing data, merge them with the worker-level wage and demographic data in the SIPP, and select our sample.

To begin, we assemble a novel and unique data on license restrictions that felons face when applying for an occupational license. In total, we identify 16,343 restrictions from a database compiled by the Criminal Justice Section of the American Bar Association (ABA). For each legal restriction, we observe the title of the state law, the state enacting the law, and whether the consequence of a felony conviction is a permanent or temporary ban from obtaining an occupational license, and whether the ban is mandatory or discretionary (non-mandatory). While we collect data on felony bans of all varieties, our analysis focuses on mandatory felony bans because they provide the cleanest signal of non-felony status. ${ }^{10}$ After filtering discretionary rules, there are 5,605 mandatory bans that exclude felons.

Since the ABA data does not include a Standard Occupation Classification code that links each restriction to a given occupation, we use an online tool developed by the Department of Labor, the SOC AutoCoder, to map the mandatory bans from the ABA database into a 6-digit SOC codes. ${ }^{11}$ We do this for all restrictions in the ABA database using a web-scrapping tool that automates the process of feeding the law titles into the SOC AutoCoder. In Appendix A.1, we provide a detailed description of the data matching process. The process includes downloading all licensing restrictions from the ABA website and integrating them into one spreadsheet. ${ }^{12}$ We then create a web-scraping algorithm that automates the matching process in the SOC AutoCoder to identify the corresponding 6-digit occupation for all restrictions. Figure A2 shows a screenshot of the

\footnotetext{
${ }^{10}$ We also do not observe how discretion operates for the laws with discretionary bans on felons.

${ }^{11}$ The SOC AutoCoder is publicly accessible online via https://www.onetsocautocoder.com/plus/ onetmatch. It uses an algorithm to match the words in a job description to the words and phrases used in the $\mathrm{O}^{*} \mathrm{Net}$ database to describe an occupation. The algorithm assigns a score to each SOC code based on the quality of the match and reports potential matches in descending order of match quality.

${ }^{12}$ In Figure A.1 of Appendix, we provide a screenshot of the raw data for a sample of laws in Alabama.
} 
output of the matching process. ${ }^{13}$

After matching the ABA law restrictions with SOC codes, it is possible for the same state-occupation to have multiple restrictions. ${ }^{14}$ If there are multiple offenses that result in different consequences for licensing eligibility, we code our felony variable to correspond to the most severe punishment. For example, in New Jersey, there are 4 legal citations for offenses that would affect an attorney's eligibility to practice law. Since "suspend attorney for any felony permanently and without discretion" is one of the four consequences, we code the attorney occupation in NJ as one with a mandatory and permanent ban on felons. When we collapse the data to unique state-by-occupation pairs, we have 2,455 state-by-occupation cells that has a mandatory ban (any duration) against felons. ${ }^{15}$ Figure 1 illustrates, for each state, the number of licensed occupations where a felony offense disqualifies a worker from obtaining an occupational license. ${ }^{16}$ Ohio, the most restrictive state, has 83 such felony bans: 59 permanent and 24 temporary. The least restrictive state, Wyoming, has 23 such felony bans: 13 permanent and 10 temporary. ${ }^{17}$ [Figure 1 here]

Because the ABA data only consists of occupational licensing laws that impose restrictions on felons, we leverage the individual self-reported licensure information from the SIPP to capture all occupational licensing requirements faced by workers - even those that do not restrict felons from having a license. The SIPP is the first national representative survey in the US to document licensure information at the individual level. ${ }^{18}$ Wave 13 of the SIPP, corresponding to September to December 2012, includes a topical

\footnotetext{
${ }^{13}$ In the replication archive, we include the raw files we download from the ABA database.

${ }^{14}$ We also have a more detailed example about multiple restrictions in Appendix A.2.

${ }^{15} 64 \%$ of the 2,455 state-occupations have a mandatory and permanent ban against felons, while another $36 \%$ have a mandatory and temporary ban.

${ }^{16}$ In Figure A3 of Appendix, we present a map based on the percent of workers (weighted by sample weight) in the banned professions.

${ }^{17}$ Eight of the ten most restricted occupations involve the licensee as a direct personal advocate or helper of the customer.

${ }^{18}$ The Institute for Justice and the National Conference of State Legislatures compiled databases for a limited set of occupations. Common licensure data that covers a national sample of workers are selfreported. They include earlier attempts from the Gallop and Westat surveys by Kleiner and Krueger (2010) and Kleiner and Krueger (2013).
} 
module "Professional Certifications, Licenses, and Educational Certificates." ${ }^{19}$ This topical module is the most extensive survey on occupational licensing to date - consisting of 10 questions on occupational licensing and certification, including whether an individual pursued a license for personal or professional reasons (Gittleman et al., 2018). A strength of the self-reported licensing data in the SIPP is that it allows us to see whether individuals report having a license in profession even if the licensing requirement in the profession is silent on a worker's criminal past. Using the SIPP data in concert with the ABA data on licensing reduces measurement error in under-counting the extent of occupational licensing and permits us to directly test if licensing reduces the black-white wage gap because it reduces asymmetric information about a worker's criminal history. Notice that although the SIPP is a longitudinal survey, the license information was only asked once during Wave 13. Thus, our license variables do not vary by time for the same worker.

Next, we harmonize our licensing variation at the state-occupation level in the SIPP. We implement a rule to convert the self-reported licensing data in the SIPP into a stateoccupation level measure of licensing. Following Blair and Chung (2019), we code a stateoccupation as licensed if $50 \%$ or more individuals in that state-occupation report having a license. ${ }^{20}$ We also examine the sensitivity of our results to the choice of the $50 \%$ threshold and show that they are robust. ${ }^{21}$ Collapsing the licensing data to the state level has additional benefits of 1) reducing measurement error in the individual self-reported license data and 2) creating state-level measures of licensing which mirror the true level of the licensing variation in the administrative law. In Table A2 in Appendix, we show that for common universally licensed professions (e.g., elementary and secondary school

\footnotetext{
${ }^{19}$ The SIPP Panel 2008 is a national longitudinal survey in the US. The entire panel consists of 16 waves from May 2008 to November 2013. Every four months, respondents answer a core group of questions about work and demographics about the preceding 4 months. A topical module with specific questions accompanies the core modules occasionally. The license information was asked once in the 2008 Panel.

${ }^{20}$ In Figure A4 of Appendix, we illustrate for each state the number of licensed occupations based on applying the $50 \%$ threshold rule to the self-reported licensing data in the SIPP.

${ }^{21}$ Kleiner and Soltas (2019) likewise collapse the licensing variation to the state-occupation level and use the percent licensed in the state-occupation pairs as their explanatory variable.
} 
teachers, registered nurses, and lawyers) that using the $50 \%$ threshold does a better job of capturing the state-occupation license status than using directly the self-reported license information.

To further explore asymmetric information as a cause of racial wage gaps observed in the SIPP, we pair our state variation in general licensing laws and licensing statues banning felons with state Ban-the-Box (BTB) policies. According to data from the National Employment Law Project (2016), the following states had BTB policies on the books at the time the SIPP licensing module was conducted: California, Colorado, Connecticut, District of Columbia, Hawaii, Massachusetts, Minnesota, and New Mexico. ${ }^{22}$

We compile our complete data set by merging the licensing data from the $\mathrm{ABA}$, the licensing data from the SIPP, and the state BTB legislation, with data on workers' employment and demographics from Wave 13 of the SIPP. For each individual in the SIPP, in addition to standard demographic and employment data, we observe the 6-digit SOC code of the occupation that they work in and their state of residence, which we use for the merge. ${ }^{23}$ We then merge data on the felony requirements of each state-occupation cell to the SIPP using state information provided in the ABA database and the predicted occupation from the SOC AutoCoder. Likewise, we merge the state BTB policy with the state variable in the SIPP data.

From this merged data set, we apply the sample restrictions by Gittleman et al. (2018). We limit our sample in Wave 13 to workers between the ages of 18 and 64 who have an implied hourly wage of between $\$ 5$ and $\$ 100 .{ }^{24}$ We dropped observations with imputed wages and imputed license status because using imputed wages would bias our estimates of the license premium toward zero since license status is not included in the imputation process (Hirsch and Schumacher, 2004). Finally, we restricted our sample to

\footnotetext{
${ }^{22} \mathrm{BTB}$ policies were binding in the public sector in all these states and in both the public and private sectors in Hawaii (Shoag and Veuger, 2021; Doleac and Hansen, 2020; Craigie, 2020).

${ }^{23}$ From the SIPP, we use data on worker wages, education, age, race, gender, and attributes of their employer and the nature of employment (e.g., union member, government worker, firm size).

${ }^{24}$ We calculate the implied hourly wage by using the monthly earnings of the primary job, hours worked per week, and number of weeks worked in that month.
} 
include only black men and non-Hispanic white men in order to explore the link between the pronounced racial and the black-white wage gap among men.

In Table 1, we report summary statistics of the final data set that we will use for our empirical analysis. The sample consists of $12.5 \%$ black men and $87.5 \%$ white men with an average age of 41 years old. Of all state-occupation pairs, 13\% are licensed with one quarter of these licenses also requiring mandatory permanent bans on felons. Just $1 \%$ of the sample reports pursuing an occupational license for personal reasons. The other $99 \%$ obtained the license for work-related reasons. The average wage in the sample is $\$ 25$ per hour. Sixty percent of workers are employed firms with fewer than 100 employees, 17\% are employed in states with BTB regulation (as of 2012), and 17\% employed in government jobs. More than $1 / 3$ of the sample reports having at least a college degree and close to $1 / 2$ of the sample reports having taken advanced math and science courses in high school. [Insert Table 1 here]

\section{Empirical Model and Regression Specification}

The aim of our empirical work is to test whether there is heterogeneity in the licensing premium by race between black men and white men. Second, we want to test whether any observed heterogeneity in the licensing premium is due to firms using the license to reduce asymmetric information between firms and workers about a worker's criminal history. In our most demanding specification, we estimate a Mincer (1958) equation of $\log$ wages as a function of whether an individual works is an occupation that is licensed. We employ a quadruple difference model that leverages difference in workers by: 1) licensed and unlicensed status 2) whether the licensed occupation imposes a mandatory permanent ban on felons 3) whether the individual works in a state with or without BTB regulation, and 4) heterogeneity by race in all the preceding differences. We also leverage heterogeneity in license premium by firm size for black and white men employed in 
occupations with mandatory permanent bans on felons.

Fundamentally, we are comparing the wages individuals who work in the same occupation but face different licensing requirements because they work in states that differ in whether they require a license or not and whether that license precludes felons from having a license and whether the state more broadly has BTB regulations in place. The exact regression specification that we run is:

$$
\begin{aligned}
\log \left(\text { wage }_{i j s m}\right)= & \beta_{0}+\beta_{1} \text { black }_{i}+\beta_{2} \text { license }_{j, s}+\beta_{3} \text { license }_{j, s} \times \text { black }_{i} \\
& +\beta_{4} \text { felonyban }_{j, s} \times \text { BTB }_{s}+\beta_{5} \text { felonyban }_{j, s} \times \text { BTB }_{s} \times \text { black }_{i} \\
& +\beta_{6} \text { felonyban }_{j, s} \times \text { nonBTB }_{s}+\beta_{7} \text { felonyban }_{j, s} \times \text { nonBTB }_{s} \times \text { black }_{i} \\
& +\Gamma X_{i}+\theta_{s}+\theta_{j}+\theta_{m}+\epsilon_{i j s m} .
\end{aligned}
$$

The dependent variable is the log of hourly wages for individual $i$ working in occupation $j$ (6-digit SOC code) in state $s$ in month $m$. The indicators black ${ }_{i}$ equal 1 if individual $i$ is black. The license indicator, license $e_{j, s}$ equals one if occupation ' $j$ ' in state ' $s$ ' requires a license as determined by our 50-50 rule. The felony ban dummy felonyban $n_{j, s}$ equals 1 if occupation ' $j$ ' in state ' $s$ ' imposes a mandatory permanent ban on felons from ever obtaining a license, as reported by the American Bar Association. The way that we define felonyban $_{j, s}=1$ is conservative and biases against us finding an effect of felony bans on wages since the control group pools both unlicensed state-occupation cells and state-occupations with discretionary and/or temporary bans on felons. ${ }^{25}$ In the main regressions, we code felonyban $_{j, s}=1$ only if license $_{j, s}=1$ defined by the $50-50$ threshold. $^{26}$ In the robustness check, we also test the sensitivity of results when we use the reverse

\footnotetext{
${ }^{25}$ In Table B1 of Appendix, we find similar results when using also temporary mandatory bans to code felonyban ${ }_{j, s}$.

${ }^{26}$ Since the SIPP licensing data comes from a survey conducted in 2012 and the ABA data is based on licensing laws as of 2015, it is possible that some of the licensing laws from the ABA data base were not in place in 2012. In coding felonyban $_{j, s}=1$ only if license $_{j, s}=1$, we mitigate measurement error due to the false positives.
} 
approach that allows the ABA data to override the 50-50 rule, i.e. if felonyban $_{j, s}=1$ then we code license $_{j, s}=1$ even if fewer than $50 \%$ of workers report having a license in the SIPP. ${ }^{27}$ To further explore the context with asymmetric information, we interact the ban indicators with whether a state have Ban-the-Box (BTB) regulations. We code $B T B_{s}=1\left(\right.$ nonBTB $\left._{s}=0\right)$ if state ' $s$ ' that has Ban-the-Box regulations, otherwise $B T B_{s}=0$ $\left(\right.$ non $\left.B T B_{s}=1\right) .{ }^{28}$ Continuing with the explanatory variables, $X$ is a vector of standard demographic characteristics including a quadratic in age, education levels (indicators for high school dropout, some college degree, college graduate, and post-graduate), indicators for union membership, self-employment, and government workers. $\theta_{s}, \theta_{m}$ and $\theta_{0}$ are the state, month and 6-digit occupation fixed effects. By using 6 digit SOC codes, our identifying variation comes from cross state differences in the licensing of the same occupation..$^{29}$ Standard errors are clustered at the state level, our level of policy variation. ${ }^{30}$

The coefficients of interests, $\beta_{2}$ to $\beta_{7}$, measure the licensing premium, the extent to which it is heterogeneous by race and the extent to which the heterogeneity in the licensing premium by race depends on the informational content of the license - in particular the extent to which the license contains unique information about a worker's felony status. We know from a very large literature that there is a racial wage gap, i.e., $\beta_{1}<0$ (Charles and Guryan, 2008). By contrast we know very little about whether the licensing premium is the same for black men as it is for white men, i.e. $\beta_{3}=0$. Our paper

\footnotetext{
${ }^{27}$ This coding reduces measurement error due to false negatives in defining the licensing variable.

${ }^{28}$ One concern over the way we assign the license regulations on workers is the issue of cross-border commuters. A worker who lives at the border of a licensed state may work in the neighboring unlicensed state to avoid the licensure requirements (e.g., felony bans). Because SIPP 2008 only contains the state of residency, not the state of employment, the measurement errors in work location may contaminate the causal estimates. We check the sensitivity of our result by analyzing SIPP 2014 in Table B5 of Appendix using the full specification. We again see that black workers earn a higher license premium in a BTB state if the license has a felony ban. Although the estimate of 'felony ban $\times$ BTB $\times$ black' is less precise, the effect size is similar to that in the main analysis.

${ }^{29}$ Gittleman et al. (2018) use 3-digit occupation fixed effects and Kleiner and Krueger (2013) 2-digit occupation fixed effects, which also allows for identifying variation to come from with-in state across occupation comparisons.

${ }^{30}$ Since SIPP is a longitudinal survey, there may be multiple observations for the same person. In the Appendix (Table B2), we show robust results using only the response of each respondent in the $4^{\text {th }}$ reference month, which is the closest month the license information was obtained.
} 
establishes evidence on this.

Given the disparity in incarceration between black men and white men, a clear implication of statistical discrimination in the labor market would be $\beta_{5}>0$, i.e., black men working in occupations that impose permanent mandatory bans on felons earn a wage premium in BTB states where it is otherwise more difficult to obtain the information about a worker's criminal past early in the job search process. We test this prediction of a model of statistical discrimination. We call $\beta_{5}$, coefficient on the interaction term 'felonyban ${ }_{j, s} \times B_{T} B_{s} \times$ black $_{i}$,' the differential ban premium because it measures the difference between black men and white men in the change in the license premium when the license has felony restriction as compared to when it does not. Positive values of the differential ban premium suggest that adding permanent mandatory felony restrictions to the license increases the licensing premium for black men in absolute terms by more than it does for white men. Our results allow us to sign the other coefficients of interest, $\beta_{4}, \beta_{6}$ and $\beta_{7}$, to better understand mechanisms through which occupational licensing affects wage gaps.

Because licensing is costly to obtain, we expect that there could be selection into licensing by individuals on unobservable characteristics. At the state level, there could also be selection in terms of which states implement licensing laws. In the following sec-

tion, we will first present our baseline results. In subsequent sections, we will quantify these two types of selection and investigate various sources of measurement error to test how robust the main results are to selection and concerns about measurement error.

\section{Results}

We have six main results to report. First, we show that we can replicate the estimates in the literature of the average licensing premium. In Column 1 of Table 2 we report the result of our regression of log wages on an indicator for whether an occupation is licensed. 
We find that the average license premium is $4.5 \%$, which is similar to the estimate of $4.8 \%$ in Gittleman et al. (2018). Having established that we can replicate the key result in the literature, we next move to show that there is substantial heterogeneity in the licensing premium by race. In Column 2 of Table 2, we add an interaction between the licensing variable and an indicator for whether the worker is black. We find that the license premium for white men is $3.6 \%$, and marginally significant (at the $10 \%$ level), but the licensing premium for black men is 12.7 percentage points (p.p.) larger at $16.3 \%$ (standard error: $5.4 \%$ ) and statistically significant at the $1 \%$ level. In fact, the licensing premium experienced by black men is large enough to overcome the racial wage gap of $10.9 \%{ }^{31}$ This is a new result in the literature.

Our hypothesis for why licensing reduces the racial wage gap is that it provides firms with information about a worker's criminal history. We test this hypothesis in three ways. First, we fully interact our licensing variable with an indicator for whether the licensing statute has a permanent mandatory ban on individuals with a felony conviction. In Column 3 of Table 2 we find suggestive evidence that licenses with restrictions on felons are associated with higher wages for both black and white men when compared to ordinary licenses that do not have mandatory permanent restrictions on ex-offenders (the point estimates are not statistical significant but are economically meaningful, i.e., larger than the average licensing premium estimated in Column 1 of Table 2). Moreover, although imprecisely estimated, we find that the license premiums in occupations with felony bans is higher for black men than to white men. This is consistent with the license functioning as a signal of felony status. We are cautious not to push this interpretation too far without further tests since the license premiums in this specification are not statistically significant.

One reason why we might have imprecise estimates of the license premium in occupations with felony restrictions could be due to the existence of heterogeneity in the

\footnotetext{
${ }^{31}$ The difference in the wages of a licensed black man and a licensed white man is 0.0181 (0.051), which is economically close to zero and also statistically indistinguishable from zero at the $5 \%$ level.
} 
licensing premium by firm size. Smaller firms, which are less likely to have human resources departments may rely more on the felony information in occupational licenses than do larger firms, which are more likely to have human resources departments that can conduct criminal background checks of potential employees and do so at scale. We test this theory by further splitting our sample into firms with fewer than 100 employees and firms with more than 100 employees and re-running the specification from Column 3 of Table 2 on these two sub-samples.

In the sample of firms with fewer than 100 employees we find that the increase in licensing premium for black men between ordinary licenses and licenses with felony restriction is 22 percentage points (p.p.) larger than the comparable increase for white men (Column 4 of Table 2). In the sample of larger firms, as reported in Column 5 of Table 2, we do not see evidence that felony ban results in differentially larger license premiums for black men, despite these felony bans increasing wages for both black men and white men by a statistically significant amount (10.0\% for white men and $12.2 \%$ for black men). In large firms, the ordinary licenses without the felony restriction gives a larger license premium for black men than white men by 18.6 p.p., which is statistically significant at the $5 \%$ level. Overall, we find that the felony information in a license differentially increases wages for black men (when compared to white men) in small firms but not large firms. The reason we find no racial wage gap is that in small firms the license functions as a signal of non-felony status for black men, whereas in larger firms the ordinary licenses equalizes the wages between white men and black men.

We have one final way for testing whether the felony information in licenses is responsible for black men experiencing a larger licensing premium than white men. In Column 6 of Table 2, we report results from a specification in which we interact our license variable with an indicator for whether there is a felony ban, and an indicator for whether the state where the individual works is a BTB state. Our hypothesis is that the larger licensing premium for black men occurs only in the occupations with felony restrictions in BTB states, 
where it is otherwise costly for firms to deduce a worker's criminal past. We find that the increase in the licensing premium for black men in occupations with felony restrictions (relative to white men) is largest (24.5 p.p.) and statistically significant at the $5 \%$ level only in BTB states. ${ }^{32}$ The series of results in Table 2 establishes that there is heterogeneity in the licensing premium by race, with black men earning a larger licensing premium than white men. This heterogeneity by race in the licensing premium is driven by firms using the license to screen workers on felon status. ${ }^{33}$ [Insert Table 2 here]

\section{How much does selection impact our results?}

Because our research design leverages state differences in licensing laws, our estimates of the licensing premiums come from computing differences in wages between individuals working in the same occupations in states that differ in their licensing requirements for that occupation. One worry that we had in doing this analysis is that there could be selection into licensing even conditional on occupation. In the presence of this type of selection on observables, we would also be concerned that selection on unobservables, which would lead to biased estimates of the licensing premiums. We have two approaches for dealing with selection. First, we estimate the extent to which there is selection on observables. Second, we use approaches in (Altonji et al., 2005) and Oster (2019) to compute the ratio of selection on unobservables to the selection on observables that would be needed for our results to be entirely driven by omitted variables bias.

\footnotetext{
${ }^{32}$ In the non-BTB states in occupations with licensing restrictions on felons, we also observe a larger increase in the licensing premium for black men than white men (12.8 p.p.). However, the point estimate is not statistically significant, and the magnitude is also smaller than from the BTB states.

${ }^{33}$ In Table B3 of Appendix, we show that the licensing premium for black men working in occupations with restrictions on felons in BTB states earn a licensing premium that 9.6 p.p. larger in the public sector than in the private sector; this difference, however, is not statistically significant. One reason for the comparatively small and imprecise estimate is that BTB regulation impacting the public sector wages can have a spillover impact on private sector wages (Doleac and Hansen, 2020).
} 


\subsection{Selection on Observables}

To access the extent of selection into occupational licensing, we look at whether individual characteristics are predictive to their license status. We regress whether an individual works in a licensed profession on observable characteristics of the individual:

$$
\mathrm{Y}_{i j s m}=\Gamma \mathrm{X}_{i}+\theta_{s}+\theta_{j}+\theta_{m}+\epsilon_{i j s m}
$$

Here $Y_{i j s m}=1$ if individual ' $\mathrm{i}$ ', working in occupation ' $\mathrm{j}$ ' in state ' $\mathrm{s}$ ' in month ' $\mathrm{m}$ ' works in a licensed profession, as defined by the $50-50$ rule. The $X_{i}$ are observable characteristics of the worker (e.g., race, age, level of education, whether the worker took advanced math, science, and English classes in high school).

In Table 3, we report results of the selection equation for whether an individual works in a licensed profession (irrespective of the restrictions on felons), whether an individual works in an occupation with a felony ban, and whether an individual works in a licensed occupation that bars felons conditional on the individual working in a licensed occupation. For each outcome, we report three sets of results: without 6-digit occupation fixed effects (Columns 1, 4, and 7 of Table 3), with occupation fixed effects (Table 3 Columns 2, 5 , and 8), and the standardized coefficients for each of the observable characteristics from the model with occupational fixed effects (Columns 3, 6, and 9 of Table 3). ${ }^{34}$

A key theme from the results in Table 3 is that once we control for occupation, observable worker demographics do not play a large role in explaining selection into licensing. For example, conditional on occupation fixed effects, only 3 of 14 demographic variables are predictive of an individual working in a licensed profession of any type (Column 2). The effect sizes are also economically small. The standardized coefficients in Column 3 suggest that a 1 standard deviation change in any of the observables at most only changes

\footnotetext{
${ }^{34}$ For the coefficient of an observable characteristic $X\left(\gamma_{x}\right)$, the corresponding standardized coefficient is the estimated coefficient from the selection model multiplied by the ratio of the the standard deviation of the observable and the standard deviation of the outcome variable: $\gamma_{s}=\frac{\gamma_{x} \sigma_{x}}{\sigma_{y}}$.
} 
the likelihood of a worker reporting a licensing by 0.1 standard deviations. When we further investigate selection into licensed occupations with felony bans, either unconditional (Column 5) or conditional (Column 8) on having a license, none of the observables significantly predicts (at the conventional 5\% level) whether an individual works in a license profession with a felony ban.

The most salient concern to our hypothesis is selection by race. The selection into general licensing by race has minimal economic impacts. Compared to a white man, black men is $3.5 \%$ less likely to work in a licensed profession (Column 2), which is only one-tenth of a standard deviation of the license variable. ${ }^{35}$ More importantly, we do not observe systemic sorting (both statistically and economically) by race into ban professions (Column 5 and 8). Therefore, the higher ban premium black men receive relative to white men is less likely driven by differential selection. [Insert Table 3 here]

At the policy level, we also present an alternative balancing test in Table B4 of Appendix to check if state-occupation license policies systematically vary with local labor market characteristics and state policy preference. The specification is slightly different than the specification in equation 1 in that we regress the state-occupation requirements in the three panels on the average worker characteristics in a state-occupation cell. We also include the state policy variables in 2013, including state minimum wage (in dollars) and right-to-work law, and the percent of Republican vote in the 2012 presidential election. We again find that none of the characteristics systemically predict the presence of felony ban, especially among licensed state-occupations.

There are a few key lessons from estimating selection into licensing which shape how we interpret the results from our study. First, selection on observables does not appear to be a major issue in our setting, conditional on the same occupation. This suggests that exploiting the across state variation in licensing laws within occupation, which is our identification strategy, yields less biased estimates than exploiting cross occupation

\footnotetext{
${ }^{35}$ Instead of the standardized coefficient in Column 3, interpretation is more meaningful to use $\frac{\gamma_{x} * 1}{\sigma_{y}}$ for a categorical variable like race.
} 
variation in licensing. Second, while there is some selection into having any license, selection into a license with a felony restriction is less concerning (especially conditional on working in a licensed occupation). These pattern of findings suggests that our results exploiting variation in the felony restrictions on licensing are less likely to be biased than the result exploiting variation in the licenses without the felony restriction.

\subsection{Selection on Unobservables}

While we have shown that there is not a lot of selection on observables, we still worry that selection on unobservables could limit our ability to estimate the causal impact of licensing on wages. To quantify how large selection on unobservables would have to be relative to selection on observables for the licensing premiums that we have estimated to equal zero, we follow the approach developed in Oster (2019), which builds on the work of Altonji et al. (2005). The Oster (2019) framework develops a consistent estimator for the relative selection on unobservables $(\delta)$. The estimate of $\delta$ is a function of the parameters from a regression of the outcome (wages) on treatment (licensing) alone; a regression of the outcome on treatment and observables; a regression of treatment on observables (which captures selection on observables); and an assumption about the size of the maximum explanatory power in a fully specified regression of the outcome on both observables and unobservables $\left(R_{\max }^{2}\right)$ as compared to the explanatory power of the fully saturated model using only observables $\left(\bar{R}^{2}\right) \cdot{ }^{36}$

$R_{\text {max }}^{2}$ is unknown to researchers. Hence, in practice, we need to make an assumption on $R_{\max }^{2}$ to calculate $\delta$. One could assume that $R_{\max }^{2}=1$ and that a fully specified model explains all the variation in an outcome. This assumption, however, is overly stringent as measurement error could reduce the explanatory power of a fully specified model. Instead, Oster (2019) suggests using a value of $R_{\max }^{2}=1.3 \bar{R}^{2}$, which is the critical value

\footnotetext{
${ }^{36}$ The notation used in Oster (2019) is $\bar{R}$ instead $\bar{R}^{2}$ and $R_{\max }$ instead of $R_{\max }^{2}$. We adapt the notation to include the squared to emphasize that $R_{\max }^{2}$ is an R-squared value.
} 
that balances the competing demands of having a value of the relative selection $(\delta)$ that has good coverage of the true treatment parameter of the model and avoiding the problem of over-rejecting the true treatment parameter. ${ }^{37}$

In Table 4, we report the estimates of relative selection on unobservables to observables that would reduce our estimated licensing premiums to zero. As a rule of thumb, both Oster (2019) and Altonji et al. (2005) suggest that selection on unobservables is unlikely to explain away a result if $|\delta|>1$. We provide estimates of $\delta$ for each licensing premium for three different values of $R_{\max }^{2}: 1$ ). a modest assumption of $\left.R_{\max }^{2}=1.1 \bar{R}^{2}, 2\right)$. the recommended assumption of $R_{\max }^{2}=1.3 \bar{R}^{2}$ from Oster (2019) (our preferred assumption), and 3). the most stringent assumption of $R_{\max }^{2}=1$.

In Panel A of Table 4, we report values of $\delta$ for the average license premium, the license premium for white men, and the license premium for black men. ${ }^{38}$ Focusing on our preferred estimates of $\delta$, which assume $R_{\max }^{2}=1.3 \bar{R}^{2}$, we find that selection on unobservables would need to be $62.3 \%$ as large as selection on observables (i.e., $\delta=0.623$ ) in order for the average license premium of $4.5 \%$ (Table 2 Column 1 ) to equal zero. Disaggregating by race, we find that the amount of relative selection on unobservables required to eliminate the licensing premium for white men is $\delta=0.622$ and for black men is $\delta=0.986$. Consequently, relative selection on unobservables could plausibly eliminate the licensing premium for white men but is less likely to eliminate the licensing premium experienced by black men, since $\delta$ for the premium for black men is larger and closer to the critical threshold of $\delta=1$. Intuitively, since the licensing premium for black men is larger than the licensing premium for white men $(16.4 \%$ versus $3.6 \%$, Table 2 Column 2$)$ and more precisely estimated (statistically significant at the $5 \%$ level for black men versus being marginally significant at the $10 \%$ level for white men), it is less likely that selection

\footnotetext{
${ }^{37}$ The critical value of $R_{\max }^{2}=1.3 \bar{R}^{2}$ in Oster (2019) was obtained by applying the bounding method to a sample of RCTs published in top economics journals. With an $R_{\max }^{2}=1.3 \bar{R}^{2}, 90 \%$ of the results in the RCT sample survive the bounding exercise in Oster (2019).

${ }^{38}$ These results come from applying the method in Oster (2019) to regressing wages on whether an individual works in an occupation with any license and the full battery of control variables first for all workers in the sample, then for the sub-sample of white workers, and then for the sub-sample of black workers.
} 
on unobservables can explain despite it being plausible that selection on unobservables can explain the licensing premium that we estimate for white men.

In Panel B of Table 4, we report values of $\delta$ for the average license premiums for ordinary licenses (those without mandatory permanent bans on felons), licenses with felony bans in non-BTB states, and licenses with felony restrictions in BTB states. ${ }^{39}$ The goal of this exercise is to test whether selection on unobservables is a larger concern for licensing premiums as a function of the type of license and how informative the license is of a worker's criminal history given the state's Ban-the-Box regulatory environment. In Panel C, we present results by licensing type, similar to Panel B, but for white men. Finally, in Panel D, we present results by license type for black men. Since our key result from Table 2 is that licensing confers a large premium for black men when the license has information about a worker's felony status and in states with BTB regulation where it is otherwise difficult to discern a worker's criminal history, it is crucial to check whether selection on unobservables is differentially important by worker's race, the license type, and the state's BTB status.

Focusing on our preferred estimates of relative selection $\left(R_{\max }^{2}=1.3 \bar{R}^{2}\right)$, across Panels B, C, and D, we find that wage premiums for ordinary licenses (without felony bans) are susceptible to concerns about selection on unobservables (i.e. $|\delta|<1$ ), whereas license premiums coming from laws that preclude felons are less susceptible to concerns about selection on unobservables (i.e. $|\delta| \geq 1$ or $|\delta| \approx 1$ ). Furthermore, we find that license premiums derived from laws with felony restrictions are less susceptible to concerns of selection on unobservables in states with BTB regulation than in states without BTB regulations. When we compare values of the relative selection for licenses with felony bans in BTB versus non-BTB states, we find the following values: $\delta=2.025$ versus $\delta=1.103$ in the sample of all workers, $\delta=1.520$ versus $\delta=1.151$ in the sample of white men, and

\footnotetext{
${ }^{39}$ These results come from applying the method in Oster (2019) to regressing wages on mutually exclusive indicator variables for whether an individual works in an occupation with an ordinary license requirement, a license with a felony restriction in a BTB state, a license with a felony restriction in a non-BTB state any license, and the full battery of control variables on the full sample of all workers.
} 
$\delta=-4.885$ versus $\delta=0.972$ in the sample of black men. ${ }^{40}$ Finally, the licensing premium for black men in occupations with felony restrictions in BTB states is the least susceptible to be driven by selection on unobservables. Even under the most conservative assumption $R_{\max }^{2}=1$, to invalidate this finding we would need selection on unobservables to be 3.181 times as large as selection on observables and moreover we would need for selection on unobservables to occur in the opposite direction to selection on observables.

\section{[Insert Table 4]}

In summary, our key finding is that selection on unobservables is unlikely to explain the licensing premium that we estimate for workers in occupations with restrictions on felons. ${ }^{41}$ Since we find that selection on unobservables matters the least in contexts where the license provides information about a worker's criminal history that is otherwise costly to obtain, selection on unobservables is unlikely to compromise our key result that licenses increase wages for black men when they provide information about a worker's criminal history that is otherwise difficult to discern.

\section{How sensitive are our results to measurement error?}

After selection bias, measurement error in our licensing variable is the second most important threat to us uncovering unbiased estimates of license premiums. Measurement error in whether an occupation is licensed is the most likely to occur for the ordinary license without felony restrictions, where we use self-reported data from respondents in the SIPP and code a state-occupation as licensed if at least $50 \%$ of respondents in that state-occupation cell report having a license.

In this section, we test the sensitivity of our results to: 1 ). choosing different thresholds

\footnotetext{
${ }^{40}$ The negative value of $\delta$ suggests that selection on unobservables would have to go in the opposite way of selection on observables for unobservables to nullify the treatment effect.

${ }^{41}$ Our finding that selection on unobservables is unlikely to nullify the licensing premiums that we estimated with felon restrictions are broadly consistent with the findings in Table 3 which shows that conditional on occupation, there is comparatively less selection on observables into licensing with restrictions on felons than there is for the licenses without restrictions on felons.
} 
to define a licensed state-occupation, 2). recoding state-occupations as licensed when we observe a license with a felon restriction in the ABA data even if it fails the $50 \%$ threshold, 3). accounting for small sample bias from the $50 \%$ threshold in state-occupation cells with few observations, 4). dropping universally licensed occupations in which there is no cross state variation in licensing laws, 5). accounting for misreport of occupation affiliation, and 6). using the individual self-reports as our measure of whether an individual has a license. Our results are unaffected by accounting for these potential sources of both classical and non-classical measurement error.

\subsection{Does changing the threshold for defining licensing matter?}

We follow the literature in defining a state to have a licensing requirement in an occupation if $50 \%$ or more of the respondents in that state-occupation cell report having a license; this threshold, however, is based on a rule of thumb (Blair and Chung, 2019). In practice, a 50\% threshold may be too stringent or not stringent enough. In this section, we first document how altering the 50\% threshold rule changes the overall fraction of individuals coded to work in licensed occupations. We further compare the fraction of workers licensed under alternative rules to two benchmarks of estimates of the prevalence of occupational licensing in the literature. We then show that the $50 \%$ threshold rule is a conservative threshold and that our results are robust to lowering the threshold.

In Figure 2, we track the percent of workers who would be classified as working in a licensed occupation if we varied the threshold from as high as $90 \%$ to as low as $10 \%$. As we make the threshold less stringent, moving from a threshold of $90 \%$ to $10 \%$ in increments of 10 percentage points, the fraction of workers predicted to have a license monotonically increases from $5 \%$ to $29 \%$. We then compare the fraction of licensed workers predicted by our varying thresholds to two benchmarks: 1 ). a lower bound of $12.7 \%$ that is tabulated from the individual survey responses of the men in the SIPP data, as reported in Table 1 and 2). an upper bound derived from the landmark studies by Kleiner and Krueger (2010) 
and Kleiner and Krueger (2013), which found that $28 \%$ of men in their specially designed surveys report being licensed. ${ }^{42}$ The $50 \%$ threshold that we use for our main analysis predicts slightly fewer licensed workers than our lower bound, whereas more conservative estimates $\geq 60 \%$, predict substantially fewer licensed workers. Because the thresholds between $10 \%$ to $40 \%$ predict fractions of licensed workers that lie in between our upper bound and lower bound, we consider these to be plausible alternative thresholds to the $50 \%$ threshold for defining whether a state-occupation is licensed. [Insert Figure 2 here]

In Table 5, we vary the threshold to define whether an state-occupation is licensed from $10 \%$ to $40 \%$. We re-estimate our wage equation from Table 2 Column 6 , in which we allow for heterogeneity in the license premium by race, whether the license imposes a restriction on felons and if it is in a BTB or non-BTB state. For each plausible threshold from $10 \%$ to $40 \%$, we find that black men working in licensed occupations with restrictions on felons in BTB states experience an addition licensing premium that ranges from 18.2 percentage points to 31.3 percentage points (in all cases the point estimate is statistically significant at the $1 \%$ level). In summary, the estimate we obtain from using the $50 \%$ threshold lies in the middle of the range of values produced from using the alternative thresholds. [Insert Table 5 here]

\subsection{Using other features of the data to reduce measurement error}

In Table 6, we report the results from several tests in which we maintain the $50 \%$ threshold for defining licensing and exploit other features of the data to reduce measurement error in the licensing variable. For each test, we re-estimate our wage equation from Table 2 Column 6 in which we allow for heterogeneity in the license premium by race, whether the license imposes a restriction on felons and if it is in a BTB or non-BTB state. Our coefficient of interest for each of these tests is the coefficient on the interaction of 'felony

\footnotetext{
${ }^{42}$ The Gallup survey in Kleiner and Krueger (2010) was conducted in 2006, whereas the Westat survey in Kleiner and Krueger (2013) was conducted in 2008.
} 
ban $\times$ BTB $\times$ black', which measures the extent to which occupational licensing confers a wage premium to black men because of the information that these laws encode about a worker's criminal past. As we showed in previous sections, this interaction is also the most economically important interaction and the least susceptible to concerns about selection on unobservables.

In Column 1 of Table 6, we report results from a strategy that reduces false negatives in whether an occupation is licensed. We require that any occupation that is noted to have a licensing restriction on felons also be coded to have a licensing requirement, i.e., if felony ban $=1$, we impose license $=1$ even if the fraction of workers self-reporting a license is below the $50 \%$ threshold. Cross-checking the 50-50 rule with the ABA data, about $11 \%$ of the unlicensed workers should have been coded as licensed according to the presence of felony ban in the ABA data. Addressing this measurement error, we find that our coefficient of interest is 0.170 and is statistically significant at the $1 \%$ level. Compared with the baseline value of 0.245 , our point estimate falls by $31 \%$, however our precision improves by $42 \%$ (standard error falls from 0.096 to 0.056 ). On net, accounting for measurement error in the self-reported licensing variable by using the administrative data on licensing from the ABA increases the confidence in our result that licensing increases wages of black men when the license functions as a signal that the worker is not a felon.

In Column 2 of Table 6, we address the problem of small sample size bias in how we define our licensing variable. We adopt a hybrid approach, using the 50\% threshold for state-occupation cells that have a moderate sample size (i.e., $N \geq 5)^{43}$ and retaining the individual survey response as our measure of licensing for state-occupation cells that have $N<5$. Under this hybrid approach for dealing with measurement error due to small sample bias, our coefficient of interest is 0.245 and is statistically significant at the $5 \%$ level. Compared with the baseline value, both our point estimate and precision remain the same. This suggests that measurement error due to small sample size bias in defining

\footnotetext{
${ }^{43}$ The $5^{\text {th }}$ percentile of the number of workers in state-occupation cell is 4 workers.
} 
our licensing variable does not impact our results.

In Column 3 of Table 6, we address the problem of measurement error in the licensing variable caused by an individual misreporting the occupation affiliation (Kambourov and Manovskii, 2008). If an individual reports his licensing status correctly but misreports his occupation, we could find that his self-report licensing status disagrees with the self-reported licensing status of the majority of workers in his state-occupation because he is in the wrong occupation. To account for measurement error in licensing due to occupation misreporting, we first create a 'misreport' indicator that equals 1 if the worker's self-reported license status disagrees with our measure of licensing. Assuming an individual who misreports his occupation (6-digit SOC code) correctly reports the broader occupation category (2-digit SOC code), we then retain the individual's self-report license status and include additional control variables in the regression - namely the 'misreport' indicator interacted with a set of 2-digit occupation dummies. In other words, we assign individuals who may report correct license status but wrong profession to a separate occupation under the same 2-digit category. Controlling for measurement error in licensing due to occupational misreporting, our coefficient of interest is 0.209 and is statistically significant at the $1 \%$ level. Compared with the baseline value, our point estimate falls by $15 \%$, however our precision improves by $29 \%$ (standard error falls from 0.096 to 0.068 ). On net, accounting for measurement error due to occupational misreporting strengthens our finding that the licensing premium is higher for black men than white men when the license contains information about a worker's criminal past that is otherwise difficult to discern.

In Column 4 of Table 6, we apply all three measurement error corrections simultaneously (from Columns 1 to 3 of Table 6). In Column 5 of Table 6, we replicate the results of Column 4 on a sample where drop all universally licensed professions defined by Gittleman et al. (2018). ${ }^{44}$ Controlling comprehensively for measurement error, in the full

\footnotetext{
${ }^{44}$ As pointed out by Gittleman et al. (2018), some individuals in the SIPP report not having a license even when they work in an occupation that is licensed in all states e.g. doctors. In principle, data from
} 
sample we find that our coefficient of interest is 0.164 and is statistically significant at the 1\% level (Table 6 Column 4). Compared with the baseline value, our point estimate of interest on 'felony ban $\times$ BTB $\times$ black' falls by $33 \%$, however our precision improves by $39 \%$ (standard error falls from 0.096 to 0.059 ). The result in the sample where we drop universally licensed occupations is both quantitatively and qualitatively similar (Table 6 Column 5). [Insert Table 6 here]

Reducing measurement error by other features of the data, we find that licenses that contain information about a worker's criminal history in BTB states (where it is otherwise difficult to ascertain information about a worker's criminal history) yield higher licensing premiums than similar licenses that preclude felons in non-BTB states, and ordinary licenses - and more so for black men than for white men. ${ }^{45}$

Finally, we test whether our results change if instead of measuring licensing using the $50 \%$ threshold, we use the naturally occurring variation from the individual self-reported license status in the SIPP. Recall that we use the 50\% rule to reduce measurement error and endogeneity concerns arising from selection on unobservables that are likely to occur in the self-reported data. Nevertheless, given the precedent for using the self-reported measures of licensing in foundational papers in the licensing literature, we assure ourselves that our results replicate when we use self-reported measures of licensing (Kleiner and Krueger, 2010, 2013; Gittleman et al., 2018).

In Table B6, we report results from regressions of wages on self-reported licensing status (for ordinary licenses) and an administrative measure of whether the license has a restriction on felons, which comes from the legal statutes underpinning the ABA data. We replicate the key findings of Table 2: the licensing premium is on average approximately 5\% (Table B6 Column 1); black men experience a larger licensing premium than white universally licensed professions do not contribute to any state variation in licensing requirements; however, including data from universally licensed occupations could improve the precision of our estimates.

${ }^{45}$ This conclusion about measurement error mirrors our finding that licenses with information about a worker's criminal history were most least likely to be affected by concerns about selection on unobservables. 
men (Table B6 Column 2) which is large enough to close the racial wage gap; larger license premium for black men is driven by the license premium to black men in occupations that preclude felons in BTB states (Table B6 Column 3 to 7). Across all of our fully interacted specifications, the point estimate on the interaction 'felony ban $\times$ BTB $\times$ black' from the models that use self-reported license status is always statistically significant at the $1 \%$ level and ranges from 0.199 to 0.217 , which overlaps with the $95 \%$ confidence intervals of the corresponding SIPP that use the 50\% threshold rule.

\section{Tests for External Validity Using Alternate Data Source}

When we started this work, the SIPP was the first and only nationally representative database with demographic information that also recorded a worker's licensing status. Since then, the Current Population Survey (CPS) has added license information of respondents. To test the external validity of our results, we use the monthly survey of Current Population Survey (CPS) in 2015, which is first year that the SIPP recorded licensing data. ${ }^{46}$ To assure comparability across our estimates from the SIPP and the Census, we adopt an identical sample selection procedure for our CPS data as in the SIPP (Section 2). Moreover, because licensure status is self-reported in the CPS, we likewise adopt a 50\% threshold - recording a state-occupation cell as licensed if at least $50 \%$ of workers in that cell self-report being licensed. In Table 7, we report results from our fully-interacted specification for licensing thresholds ranging from $10 \%$ to $50 \%$. The ban premium for black men in BTB states ('felony ban $\times$ BTB $\times$ black') consistently shows significantly and ranges from 0.126 to 0.194 . This range of magnitudes is also similar to the estimates we obtain using SIPP. ${ }^{47}$ [Insert Table 7 here]

\footnotetext{
${ }^{46}$ In Table B7 of Appendix, we also compare the key demographics of the men sample in the two surveys.

${ }^{47}$ In Column 6, we also check the sensitivity using individual attainment instead of a threshold to define the license variable. We again observe a similar result that black men earn a substantially higher ban premium in BTB states.
} 


\section{Conclusion}

Using newly constructed data on the felony restrictions imposed by occupational licenses, we find evidence that asymmetric information concerning a worker's criminal history affects wage setting behavior in the labor market. In contexts where firms can infer from licensing restrictions that black male workers are not felons, we find the highest relative returns to occupational licensing for black men. It is surprising that even historically discriminatory labor market institutions like occupational licensing, which in some states and some occupations were set up specifically to exclude blacks, can provide the labor market with useful information, which itself can undermine the taste-based discrimination responsible for the creation of the licensing statues in the the first place (Summers, 1946). ${ }^{48}$ This insight mirrors the core finding of Spence (1973) - high-cost signals are informative because they are costly.

From this study, we learn that occupational licenses without any felony information confer economically small wage premiums to both white men and black men. Given the evidence in the literature of the large negative labor supply effects of licensing, the negligible wage impacts of these ordinary license without felony information, which account for three quarters of licenses, suggest that incumbents in licensed occupations are benefiting far less from keeping others out than previously thought (Kleiner and Soltas, 2019; Blair and Chung, 2019; Farronato et al., 2020; Blair and Fisher, 2021). By this measure, occupational licensing that lacks other useful labor market signals, e.g., information about a worker's criminal history, look far less efficient than previously appreciated - they cause a large quantity distortion with a comparatively small wage increase for licensed workers. This reading of the modern empirical literature on occupational licensing supports the conceptual point made in Friedman (1962) that licensing has potentially large negative effects on welfare.

\footnotetext{
${ }^{48}$ Indeed, closing the racial gap in incarceration among men can play a role is closing the stubborn racial wage gap documented in Bayer and Charles (2018).
} 
Providing information about a worker's criminal history through occupational licensing is clearly not a first-best solution to address asymmetric information in the labor market; nevertheless, licensing laws that impose permanent mandatory bans on felons allow for a separating equilibrium in the labor market in which firms screen workers on their criminal past. In the absence of this information on workers' criminal histories, it is theoretically possible that firms could hire even fewer black men due to market unravelling (Akerlof, 1970). One of the first best solutions to reduce income inequality by race involves dealing with the forces that generate the racial disparity in contact with the criminal justice system in the first place.

\section{References}

AGAN, A. AND S. STARR (2018): “Ban the box, criminal records, and racial discrimination: A field experiment," The Quarterly Journal of Economics, 133, 191-235.

AKERLOF, G. A. (1970): “The Market for 'Lemons': Quality Uncertainty and the Market Mechanism," The Quarterly Journal of Economics, 488--500.

Altonji, J. G., T. E. Elder, And C. R. TAber (2005): “Selection on observed and unobserved variables: Assessing the effectiveness of Catholic schools," Journal of Political Economy, 113, 151-184.

Altonji, J. G. And C. R. Pierret (2001): “Employer learning and statistical discrimination," Quarterly Journal of Economics, 116, 313-350.

Arcidiacono, P., P. BAyer, AND A. Hizmo (2010): “Beyond Signaling and Human Capital: Education and the Revelation of Ability," American Economic Journal: Applied Economics, 2, 76-104.

ARROW, K. (1973): "The Theory of Discrimination," in Discrimination in Labor Markets, ed. by O. Ashenfelter and A. Rees, Princeton, NJ: Princeton University Press. 
Autor, D. H. And D. Scarborough (2008): “Does Job Testing Harm Minority Workers? Evidence from Retail Establishments," Quarterly Journal of Economics, 123, 219—-77.

BAYER, P. AND K. K. CHARles (2018): “Divergent paths: A new perspective on earnings differences between black and white men since 1940," The Quarterly Journal of Economics, $133,1459-1501$.

BECKer, G. (1957): The Economics of Discrimination, Chicago: University of Chicago Press.

BLAIR, P. Q. AND B. W. CHUnG (2019): “How Much of Barrier to Entry is Occupational Licensing?" British Journal of Industrial Relations.

- (2021): "A model of occupational licensing and statistical discrimination," in $A E A$ Papers and Proceedings, vol. 111, 201-05.

BlaIR, P. Q. AND M. FISHER (2021): “Occupational Licensing in the Digital Economy," NBER Working Papers.

Charles, K. K. And J. Guryan (2008): “Prejudice and wages: an empirical assessment of Becker's The Economics of Discrimination," Journal of Political Economy, 116, 773-809.

Chetty, R., N. Hendren, M. R. Jones, And S. R. Porter (2020): “Race and Economic Opportunity in the United States: an Intergenerational Perspective," Quarterly Journal of Economics, 135, 711-783.

CHUNG, B. W. (2022): “The costs and potential benefits of occupational licensing: A case of real estate license reform," Labour Economics, 76, 102172.

Chung, B. W., J. ZOU, ET AL. (2021): “Teacher Licensing, Teacher Supply, and Student Achievement: Nationwide Implementation of edTPA," HCEO Working Papers.

CoAte, S. AND G. C. LOURY (1993): “Will Affirmative Action Policies Eliminate Negative Stereotypes?" American Economic Review, 83, 1220-40. 
Craigie, T.-A. (2020): “Ban the Box, Convictions and Public Employment," Economic Inquiry, 58, 425-445.

De Tray, D. (1982): "Veteran Status as a Screening Device," American Economic Review, $72,133-142$.

Doleac, J. L. AND B. HANSEN (2020): "The unintended consequences of "ban the box": Statistical discrimination and employment outcomes when criminal histories are hidden," Journal of Labor Economics, 38, 321-374.

Farronato, C., A. Fradkin, B. Larsen, and E. Brynjolfssson (2020): “Consumer Protection in an Online World: An Analysis of Occupational Licensing," Working Paper 26601, National Bureau of Economic Research.

Friedman, M. (1962): Capitalism and Freedom, Chicago: University of Chicago Press.

Gittleman, M., M. A. KleE, And M. M. Kleiner (2018): “Analyzing the Labor Market Outcome of Occupational Licensing," Industrial Relations: A Journal of Economy and Society, $57,57-100$.

Goldsmith, A. H., D. Hamilton, And W. Darity JR. (2006): "Does a Foot in the Door Matter? White-Nonwhite Differences in the Wage Return to Tenure and Prior Workplace Experience," The Southern Economic Journal, 73, 267-306.

Gomez, R., M. Gunderson, X. HuAng, And T. Zhang (2015): “Do immigrants gain or lose by occupational licensing?" Canadian Public Policy, 41, S80-S97.

HiRSCH, B. T. AND E. J. SCHUMACHER (2004): “Match bias in wage gap estimates due to earnings imputation," Journal of Labor Economics, 22, 689-722.

Holzer, H. J., S. Raphael, AND M. A. Stoll (2006): “Perceived Criminality, Criminal Background Checks, and the Racial Hiring Practices of Employers," Journal of Law and Economics, 49, 451-480. 
KAMBOUROV, G. AND I. MANOVSKII (2008): “Rising occupational and industry mobility in the United States: 1968-97," International Economic Review, 49, 41-79.

Kleiner, M. And A. Krueger (2010): “The Prevalence and Effects of Occupational Licensing," British Journal of Industrial Relations, 48, 676-687.

(2013): “Analyzing the Extent and Influence of Occupational Licensing on the Labor Market," Journal of Labor Economics, 31, S173-S202.

Kleiner, M. M. AND E. J. SOltAS (2019): “A Welfare Analysis of Occupational Licensing in U.S. States," NBER Working Papers.

Koumenta, M. And M. Pagliero (2018): “Occupational Licensing in the European Union: Coverage and Wage Effects," CEPR Discussion Paper.

LAW, M. T. AND M. S. MARKS (2012): “Effects of Occupational Licensing Laws on Minorities: Evidence from the Progressive Era," The Journal of Law and Economics, 52, 351366.

Miller, C. (2017): “The Persistent Effect of Temporary Affirmative Action," American Economic Journal: Applied Economics, 9, 152-90.

MinceR, J. (1958): “Investment in Human Capital and Personal Income Distribution," Journal of Political Economy, 66, 281-302.

NunN, N. AND L. WANTCHEKON (2011): “The Slave Trade and the Origins of Mistrust in Africa," American Economic Review, 101, 3221-52.

Oster, E. (2019): “Unobservable selection and coefficient stability: Theory and evidence," Journal of Business \& Economic Statistics, 37, 187-204.

PAger, D. (2003): “Employer Learning and Statistical Discrimination," American Journal of Sociology, 108, 937-975. 
Pager, D., B. Western, AND N. Sugie (2009): “Sequencing Disadvantage: Barriers to Employment Facing Young Black and White Men with Criminal Records," Annals of the American Academy of Political and Social Sciences, 623, 195-213.

Phelps, E. (1972): "The Statistical Theory of Racism and Sexism," American Economic Review, 62, 659-661.

Pizzola, B. And A. TABarroK (2017): “Occupational Licensing Causes a Wage Premium: Evidence from a Natural Experiment in Colorado's Funeral Services Industry," International Review of Law and Economics, 50, 50-59.

ShoAG, D. AND S. Veuger (2021): “Ban-the-Box Measures Help High-Crime Neighborhoods," The Journal of Law and Economics, 64, 85-105.

SPENCE, M. (1973): “Job Market Signaling," Quarterly Journal of Economics, 87, 355-74.

Summers, C. W. (1946): “Admission Policies of Labor Unions Author,” Quarterly Journal of Economics, 61, 66-107.

WozNiAK, A. (2015): “Discrimination and the Effects of Drug Testing on Black Employment," Review of Economics and Statistics, 97, 548-566. 


\section{Tables and Figures}

Figure 1: The Number of Occupational Licenses in a State that Preclude Felons

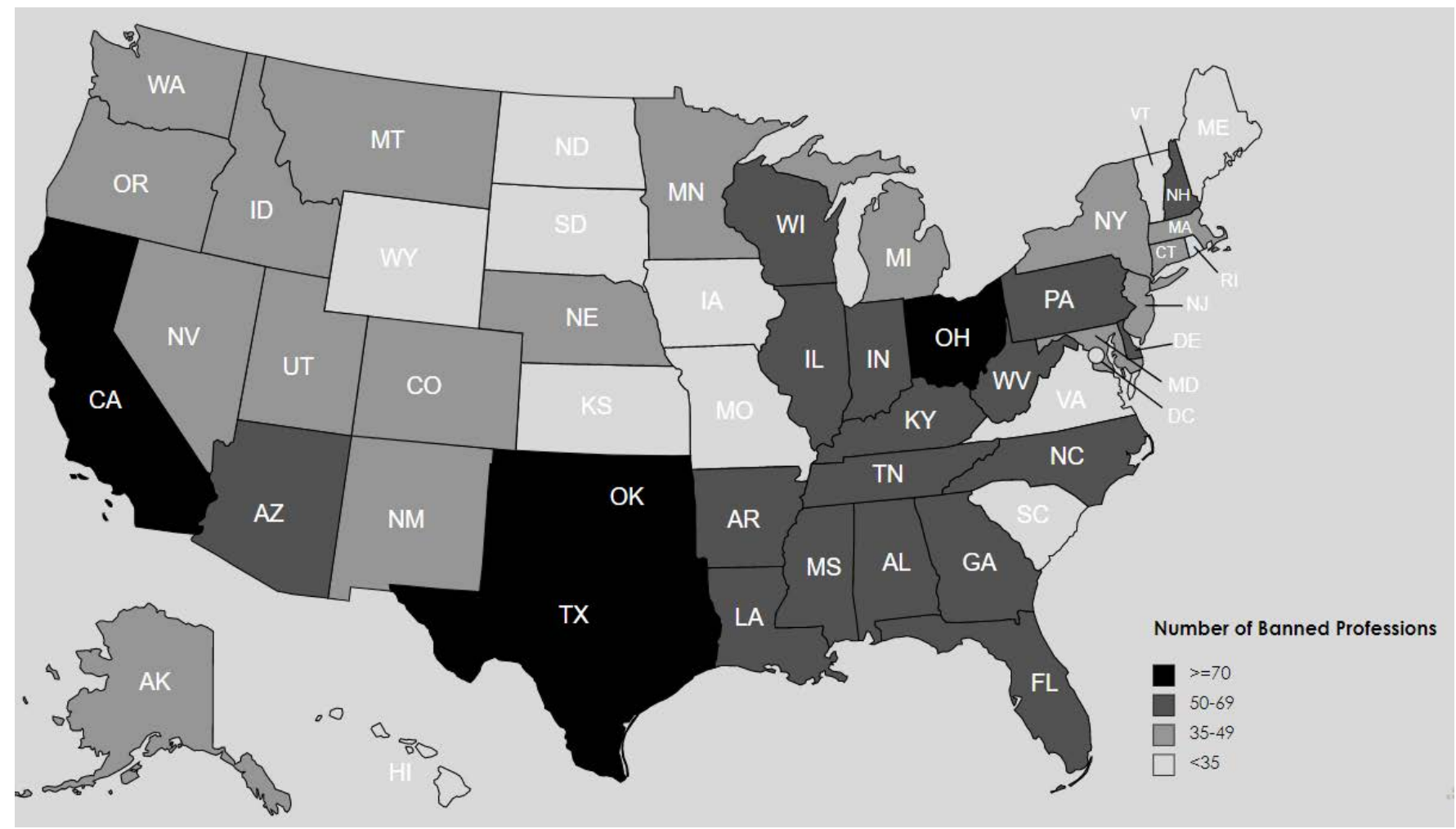

Note: This map depicts the number of occupations in each state that places mandatory restrictions on felons from having an occupational license. The states shaded in with darker color have more licensed professions with a felony restriction. The dataset is generated using the American Bar Association Database (2016) and a web scrapping tool for matching legal restriction onto occupations. 


\section{Table 1: Summary Statistics of the License and Demographic Data}

\begin{tabular}{lcccc}
\hline \hline & mean & sd & min & max \\
\hline $\begin{array}{l}\text { Occupation-level license variables: } \\
\text { license }\end{array}$ & 0.126 & 0.332 & 0 & 1 \\
felony ban & 0.037 & 0.189 & 0 & 1 \\
\multicolumn{1}{l}{$\begin{array}{l}\text { Demographic/Employment variables: } \\
\text { hourly wage }\end{array}$} & & & \\
age & 25.07 & 15.46 & 5 & 99 \\
black & 41.23 & 12.24 & 18 & 64 \\
small firm ( $\leq 100$ employees) & 0.125 & 0.331 & 0 & 1 \\
BTB state & 0.596 & 0.491 & 0 & 1 \\
less than high school (HS) & 0.166 & 0.372 & 0 & 1 \\
high school & 0.039 & 0.194 & 0 & 1 \\
some college & 0.247 & 0.431 & 0 & 1 \\
college & 0.360 & 0.480 & 0 & 1 \\
postgrad & 0.237 & 0.425 & 0 & 1 \\
union & 0.117 & 0.322 & 0 & 1 \\
government worker & 0.142 & 0.349 & 0 & 1 \\
self-employed & 0.169 & 0.375 & 0 & 1 \\
service & 0.031 & 0.175 & 0 & 1 \\
took English Lit. in HS & 0.400 & 0.490 & 0 & 1 \\
took Advanced Math. in HS & 0.700 & 0.458 & 0 & 1 \\
took Advanced Science in HS & 0.544 & 0.498 & 0 & 1 \\
obtained license for personal reason & 0.526 & 0.499 & 0 & 1 \\
\hline Observations & 0.011 & 0.105 & 0 & 1 \\
\hline \hline
\end{tabular}

Data Source: Wave 13 of SIPP Panel 2008; American Bar Association Database (2016).

Notes: The sample is restricted to respondents aged 18-64 with hourly wages on the main job between $\$ 5$ and $\$ 100$ from September to December 2012. Only men who are black or non-Hispanic white are included. Observations with imputed wages and license status are dropped. The variable 'license' equals 1 based on the 50-50 rule (a state-specific 6 digit-level occupation requires a license if $50 \%$ or more respondents in that cell reported having a license in SIPP). 'Ban' indicator equals 1 refers to a license with permanent felony ban. Ban-the-Box (BTB) states refer to state implemented statewide BTB law in the public or private sector. They include California, Colorado, Connecticut, DC, Hawaii, Massachusetts, Minnesota, and New Mexico. Sample weights apply. 
Table 2: Black men earn larger licensing premium than white men

\begin{tabular}{|c|c|c|c|c|c|c|}
\hline & $\begin{array}{c}(1) \\
\text { Base }\end{array}$ & $\begin{array}{c}(2) \\
\text { Race }\end{array}$ & $\begin{array}{l}\text { (3) } \\
\text { Ban }\end{array}$ & $\begin{array}{c}(4) \\
\text { firm size } \\
\leq 100\end{array}$ & $\begin{array}{c}(5) \\
\text { firm size } \\
>100\end{array}$ & $\begin{array}{c}(6) \\
\text { BTB Laws }\end{array}$ \\
\hline black & $\begin{array}{c}-0.0994^{* * *} \\
(0.0173)\end{array}$ & $\begin{array}{c}-0.109^{* * *} \\
(0.0178)\end{array}$ & $\begin{array}{c}-0.108^{* * *} \\
(0.0177)\end{array}$ & $\begin{array}{c}-0.133^{* * *} \\
(0.0222)\end{array}$ & $\begin{array}{c}-0.0954^{* * *} \\
(0.0270)\end{array}$ & $\begin{array}{l}-0.108^{* * *} \\
(0.0178)\end{array}$ \\
\hline license & $\begin{array}{l}0.0448^{* *} \\
(0.0183)\end{array}$ & $\begin{array}{c}0.0359^{*} \\
(0.0187)\end{array}$ & $\begin{array}{c}0.0246 \\
(0.0229)\end{array}$ & $\begin{array}{c}0.0331 \\
(0.0294)\end{array}$ & $\begin{array}{c}0.0104 \\
(0.0279)\end{array}$ & $\begin{array}{c}0.0246 \\
(0.0230)\end{array}$ \\
\hline license $\times$ black & & $\begin{array}{c}0.127^{* *} \\
(0.0534)\end{array}$ & $\begin{array}{c}0.0689 \\
(0.0707)\end{array}$ & $\begin{array}{c}0.0297 \\
(0.0588)\end{array}$ & $\begin{array}{c}0.186^{* *} \\
(0.0907)\end{array}$ & $\begin{array}{c}0.0687 \\
(0.0709)\end{array}$ \\
\hline felony ban & & & $\begin{array}{c}0.0529 \\
(0.0346)\end{array}$ & $\begin{array}{c}0.0366 \\
(0.0452)\end{array}$ & $\begin{array}{c}0.100^{* *} \\
(0.0477)\end{array}$ & \\
\hline felony ban $\times$ black & & & $\begin{array}{c}0.168 \\
(0.126)\end{array}$ & $\begin{array}{l}0.221^{* *} \\
(0.100)\end{array}$ & $\begin{array}{l}0.0227 \\
(0.235)\end{array}$ & \\
\hline felony ban $\times$ BTB & & & & & & $\begin{array}{c}0.0758 \\
(0.0553)\end{array}$ \\
\hline felony ban $\times$ BTB $\times$ black & & & & & & $\begin{array}{c}0.245^{* *} \\
(0.0963)\end{array}$ \\
\hline felony ban $\times$ nonBTB & & & & & & $\begin{array}{c}0.0455 \\
(0.0347)\end{array}$ \\
\hline felony ban $\times$ nonBTB $\times$ black & & & & & & $\begin{array}{c}0.128 \\
(0.156)\end{array}$ \\
\hline Constant & $\begin{array}{l}2.108^{* * *} \\
(0.0759)\end{array}$ & $\begin{array}{l}2.106^{* * *} \\
(0.0758)\end{array}$ & $\begin{array}{l}2.107^{* * *} \\
(0.0753)\end{array}$ & $\begin{array}{l}2.176^{* * *} \\
(0.0888)\end{array}$ & $\begin{array}{c}2.115^{* * *} \\
(0.134)\end{array}$ & $\begin{array}{l}2.107^{* * *} \\
(0.0756)\end{array}$ \\
\hline Observations & 30,256 & 30,256 & 30,256 & 18,015 & 12,241 & 30,256 \\
\hline R-squared & 0.560 & 0.560 & 0.561 & 0.558 & 0.606 & 0.561 \\
\hline
\end{tabular}

Data Source: Wave 13 of SIPP Panel 2008; American Bar Association Database.

Notes: Dependent variable is the log of hourly wage. The 'license' variable is based on the 50-50 rule (a state-specific 6 digit-level occupation requires a license if $50 \%$ or more respondents in that particular cell reported having a license in SIPP). 'Felony ban' indicator equals 1 only if 'license' equals 1. Ban-The-Box (BTB) states refer to state implemented statewide BTB law in the public or private sector. They include California, Colorado, Connecticut, DC, Hawaii, Massachusetts, Minnesota, and New Mexico. The sample is restricted to male workers who are white or black. Hispanics and workers of other races are excluded. All regressions include month, state, and 6-digit occupation fixed effects. Individual controls include a quadratic in age, education levels, union status, a government worker indicator, a self-employed indicator, a service worker indicator. In addition, we include indicators for 'certification' and 'license not required for jobs.' The sample is restricted to respondents aged 18-64 with hourly wages on the main job between $\$ 5$ and $\$ 100$. Observations with imputed wages and license status are dropped. All regressions are weighted by sampling weight. Standard errors are clustered at the state level. ${ }^{* * *},{ }^{* *}$, * correspond to 1\%, 5\%, $10 \%$ significance level, respectively. 


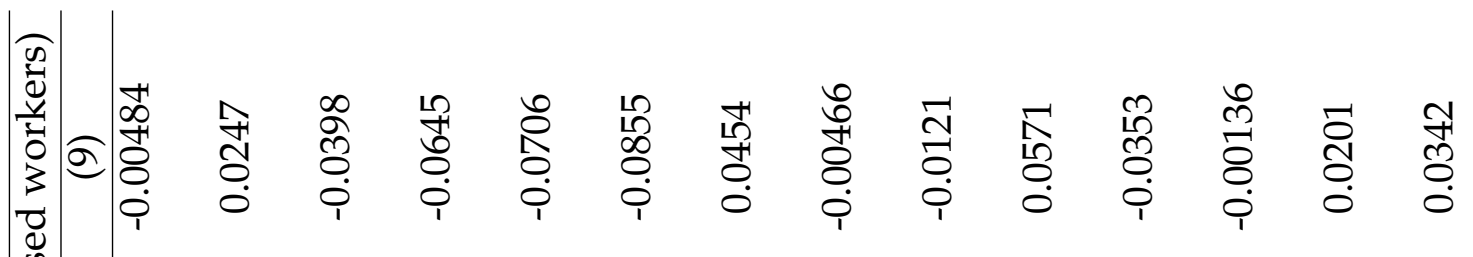


Table 4: Tests for the relevance of selection on unobservables

\begin{tabular}{lccc}
\hline \hline Assumption on $R_{\max }^{2}$ & $R_{\max }^{2}=1.1 \bar{R}^{2}$ & $R_{\max }^{2}=1.3 \bar{R}^{2}$ & $R_{\max }^{2}=1$ \\
\hline & & & \\
A: License Premium (Any License) & & & \\
\hline Full Sample & 1.985 & 0.623 & 0.227 \\
White Men & 1.920 & 0.622 & 0.229 \\
Black Men & 3.059 & 0.986 & 0.644 \\
& & & \\
B: License Premium by Type (All) & & & \\
\hline Ordinary (no mandatory ban) & 2.285 & 0.712 & 0.259 \\
License w/ Ban in non-BTB states & 3.529 & 1.103 & 0.401 \\
License w/ Ban in BTB states & 6.484 & 2.025 & 0.736 \\
& & & \\
C: License Premium (White Men) & & & \\
\hline Ordinary (no mandatory ban) & 2.443 & 0.788 & 0.289 \\
License w/ Ban in non-BTB states & 3.559 & 1.151 & 0.422 \\
License w/ Ban in BTB states & 4.708 & 1.520 & 0.558 \\
& & & \\
D: License Premium (Black Men) & & & \\
\hline Ordinary (no mandatory ban) & 1.377 & 0.431 & 0.279 \\
License w/ Ban in non-BTB states & 3.087 & 0.972 & 0.632 \\
License w/ Ban in BTB states & -15.347 & -4.885 & -3.181 \\
& & & \\
\hline \hline
\end{tabular}

Note: The number of each cell represents the size of relative selection on unobservables $(\delta)$ for the corresponding license premium to equal zero (Oster, 2019). The bigger the absolute value, the less likely our estimates are biased by unmeasured selection. 
Figure 2: Plausible alternative thresholds for the license definition

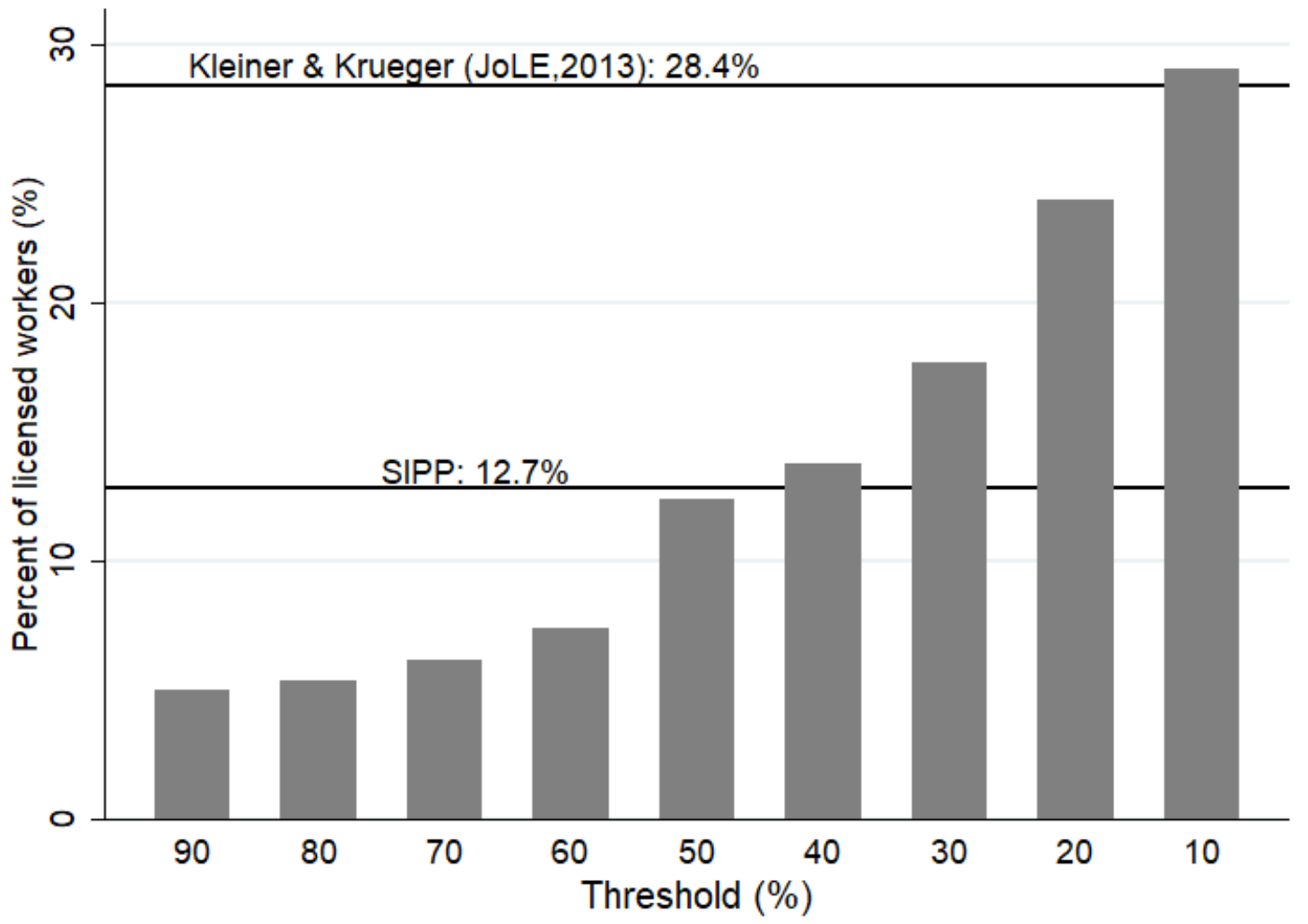

Note: The bars represent the percent of licensed (male) workers in the SIPP under cutoff values ranging from $90 \%$ to $10 \%$. Under a cutoff threshold of $50 \%$, for example, we code a state-occupation as licensed if $50 \%$ of the workers in that cell self-report to having a license in the SIPP data. For comparison, the upper bound is the percent of licensed workers in the Westat survey used in Kleiner and Krueger (2013) and the lower bound is the tabulated percent using the raw response in the SIPP calculated in Table 1. 
Table 5: Tests for the robustness of results to alternative thresholds $\leq 50 \%$

\begin{tabular}{|c|c|c|c|c|c|}
\hline & (1) & (2) & (3) & (4) & (5) \\
\hline & \multicolumn{5}{|c|}{ Define a licensed occupation if percent of licensed at least } \\
\hline & $10 \%$ & $20 \%$ & $30 \%$ & $40 \%$ & $50 \%$ \\
\hline \multirow[t]{2}{*}{ black } & $-0.126^{* * *}$ & $-0.122^{* * *}$ & $-0.114^{* * *}$ & $-0.110^{* * *}$ & $-0.108^{* * *}$ \\
\hline & $(0.0216)$ & $(0.0213)$ & $(0.0173)$ & $(0.0177)$ & $(0.0178)$ \\
\hline \multirow[t]{2}{*}{ license } & 0.0176 & 0.00284 & 0.00211 & 0.0109 & 0.0246 \\
\hline & (0.0157) & $(0.0163)$ & $(0.0187)$ & $(0.0229)$ & $(0.0230)$ \\
\hline \multirow[t]{2}{*}{ license $\times$ black } & $0.103^{* * *}$ & $0.110^{* * *}$ & $0.0933^{*}$ & 0.0584 & 0.0687 \\
\hline & $(0.0378)$ & $(0.0388)$ & $(0.0550)$ & $(0.0668)$ & $(0.0709)$ \\
\hline \multirow[t]{2}{*}{ felony ban $\times$ BTB } & $0.0596^{* *}$ & $0.0511^{*}$ & $0.0822^{* *}$ & 0.0785 & 0.0758 \\
\hline & $(0.0281)$ & $(0.0300)$ & $(0.0401)$ & $(0.0515)$ & $(0.0553)$ \\
\hline \multirow[t]{2}{*}{ felony ban $\times$ BTB $\times$ black } & $0.182^{* * *}$ & $0.183^{* * *}$ & $0.284^{* * *}$ & $0.313^{* * *}$ & $0.245^{* *}$ \\
\hline & $(0.0444)$ & $(0.0461)$ & $(0.0665)$ & $(0.0798)$ & $(0.0963)$ \\
\hline \multirow[t]{2}{*}{ felony ban $\times$ nonBTB } & 0.0198 & 0.0258 & 0.0309 & 0.0372 & 0.0455 \\
\hline & $(0.0229)$ & $(0.0238)$ & $(0.0277)$ & $(0.0352)$ & $(0.0347)$ \\
\hline \multirow[t]{2}{*}{ felony ban $\times$ nonBTB $\times$ black } & -0.0891 & -0.0791 & -0.0181 & 0.0333 & 0.128 \\
\hline & $(0.0753)$ & $(0.0779)$ & $(0.0934)$ & $(0.109)$ & $(0.156)$ \\
\hline \multirow[t]{2}{*}{ Constant } & $2.106^{* * *}$ & $2.106^{* * *}$ & $2.108^{* * *}$ & $2.109^{* * *}$ & $2.107^{* * *}$ \\
\hline & $(0.0761)$ & $(0.0758)$ & $(0.0756)$ & $(0.0748)$ & $(0.0756)$ \\
\hline Observations & 30,256 & 30,256 & 30,256 & 30,256 & 30,256 \\
\hline R-squared & 0.561 & 0.561 & 0.561 & 0.561 & 0.561 \\
\hline
\end{tabular}

Data Source: Wave 13 of SIPP Panel 2008; American Bar Association Database.

Notes: Dependent variable is the log of hourly wage. 'Felony ban' indicator equals 1 if 'license' equals 1 . Ban-the-Box (BTB) states refer to state implemented statewide BTB law in the public or private sector. They include California, Colorado, Connecticut, DC, Hawaii, Massachusetts, Minnesota, and New Mexico. The sample is restricted to male workers who are white or black. Hispanics and workers of other races are excluded.

All regressions include month, state, and 6-digit occupation fixed effects. Individual controls include a quadratic in age, education levels, union status, a government worker indicator, a self-employed indicator, a service worker indicator. In addition, we include indicators for 'certification', 'license not required for jobs.' The sample is restricted to respondents aged 18-64 with hourly wages on the main job between $\$ 5$ and $\$ 100$. Observations with imputed wages and license status are dropped. All regressions are weighted by sampling weight. Standard errors are clustered at the state level. ***, $* *$, * correspond to $1 \%, 5 \%, 10 \%$ significance level, respectively. 
Table 6: Tests for the impact of measurement error on our results

\begin{tabular}{|c|c|c|c|c|c|}
\hline & $\begin{array}{c}(1) \\
\text { license }=1 \text { if ban=1 }\end{array}$ & $\begin{array}{c}(2) \\
\text { Hybrid } \\
\end{array}$ & $\begin{array}{c}\text { (3) } \\
\text { Occupational Misreporting }\end{array}$ & $\begin{array}{c}(4) \\
\text { All criterion }\end{array}$ & $\begin{array}{c}(5) \\
\text { All criterion } \\
\end{array}$ \\
\hline black & $\begin{array}{l}-0.114^{* * *} \\
(0.0217)\end{array}$ & $\begin{array}{l}-0.108^{* * *} \\
(0.0178)\end{array}$ & $\begin{array}{l}-0.109^{* * *} \\
(0.0185)\end{array}$ & $\begin{array}{l}-0.113^{* * *} \\
(0.0210)\end{array}$ & $\begin{array}{l}-0.117^{* * *} \\
(0.0209)\end{array}$ \\
\hline license & $\begin{array}{l}-0.00320 \\
(0.0196)\end{array}$ & $\begin{array}{c}0.0246 \\
(0.0230)\end{array}$ & $\begin{array}{l}0.0432^{* *} \\
(0.0175)\end{array}$ & $\begin{array}{c}0.0301 \\
(0.0208)\end{array}$ & $\begin{array}{c}0.0298 \\
(0.0209)\end{array}$ \\
\hline license $\times$ black & $\begin{array}{c}0.0665 \\
(0.0580)\end{array}$ & $\begin{array}{c}0.0683 \\
(0.0700)\end{array}$ & $\begin{array}{l}0.0750 \\
(0.0466)\end{array}$ & $\begin{array}{c}0.0654 \\
(0.0597)\end{array}$ & $\begin{array}{c}0.0699 \\
(0.0693)\end{array}$ \\
\hline felony ban $\times$ BTB & $\begin{array}{c}0.0343 \\
(0.0286)\end{array}$ & $\begin{array}{c}0.0757 \\
(0.0553)\end{array}$ & $\begin{array}{c}0.0237 \\
(0.0357)\end{array}$ & $\begin{array}{l}0.0573^{* *} \\
(0.0271)\end{array}$ & $\begin{array}{l}0.106^{* *} \\
(0.0482)\end{array}$ \\
\hline felony ban $\times$ BTB $\times$ black & $\begin{array}{l}0.170^{* * *} \\
(0.0556)\end{array}$ & $\begin{array}{l}0.245^{* *} \\
(0.0955)\end{array}$ & $\begin{array}{l}0.209^{* * *} \\
(0.0677)\end{array}$ & $\begin{array}{l}0.164^{* * *} \\
(0.0592)\end{array}$ & $\begin{array}{l}0.180^{* *} \\
(0.0749)\end{array}$ \\
\hline felony ban $\times$ nonBTB & $\begin{array}{c}0.0174 \\
(0.0221)\end{array}$ & $\begin{array}{c}0.0455 \\
(0.0347)\end{array}$ & $\begin{array}{c}0.0219 \\
(0.0301)\end{array}$ & $\begin{array}{c}0.0376 \\
(0.0232)\end{array}$ & $\begin{array}{l}0.0596^{* *} \\
(0.0271)\end{array}$ \\
\hline felony ban $\times$ nonBTB $\times$ black & $\begin{array}{l}-0.0721 \\
(0.0866)\end{array}$ & $\begin{array}{l}0.128 \\
(0.155)\end{array}$ & $\begin{array}{c}0.0564 \\
(0.0984)\end{array}$ & $\begin{array}{l}-0.0729 \\
(0.0870)\end{array}$ & $\begin{array}{l}-0.0841 \\
(0.0991)\end{array}$ \\
\hline Constant & $\begin{array}{l}2.108^{* * * *} \\
(0.0739)\end{array}$ & $\begin{array}{l}2.107^{* * *} \\
(0.0756)\end{array}$ & $\begin{array}{l}2.132^{* * * *} \\
(0.0748)\end{array}$ & $\begin{array}{l}2.108^{* * *} \\
(0.0763)\end{array}$ & $\begin{array}{l}2.111^{* * *} \\
(0.0757)\end{array}$ \\
\hline Sample & Full & Full & Full & Full & Dropped Universal \\
\hline Observations & 30,256 & 30,256 & 30,256 & 30,256 & 27,530 \\
\hline R-squared & 0.560 & 0.561 & 0.564 & 0.563 & 0.569 \\
\hline
\end{tabular}

Data Source: Wave 13 of SIPP Panel 2008; American Bar Association Database.

Notes: Dependent variable is the log of hourly wage. Ban-the-Box (BTB) states refer to state implemented statewide BTB law in the public or private sector. They include California, Colorado, Connecticut, DC, Hawaii, Massachusetts, Minnesota, and New Mexico. The sample is restricted to male workers who are white or black. Hispanics and workers of other races are excluded.

All regressions include month, state, and 6-digit occupation fixed effects. Individual controls include a quadratic in age, education levels, union status, a government worker indicator, a self-employed indicator, a service worker indicator. In addition, we include indicators for 'certification', 'license not required for jobs.' The sample is restricted to respondents aged 18-64 with hourly wages on the main job between $\$ 5$ and $\$ 100$. Observations with imputed wages and license status The sample is restricted to respondents aged $18-64$ with hourly wages on the main job between $\$ 5$ and $\$ 100$. Observations with imputed wages and license status
are dropped. All regressions are weighted by sampling weight. Standard errors are clustered at the state level. ${ }^{* * *}, * *,{ }^{*}$ correspond to $1 \%, 5 \%, 10 \%$ significance level, respectively. 
Table 7: Tests for external validity using data from Current Population Survey

\begin{tabular}{|c|c|c|c|c|c|c|}
\hline & (1) & (2) & (3) & (4) & (5) & (6) \\
\hline & \multicolumn{5}{|c|}{ Define a licensed occupation if percent of licensed at least: } & self-report \\
\hline & $10 \%$ & $20 \%$ & $30 \%$ & $40 \%$ & $50 \%$ & license status \\
\hline \multirow[t]{2}{*}{ black } & $-0.121^{* * *}$ & $-0.120^{* * *}$ & $-0.131^{* * *}$ & $-0.129^{* * *}$ & $-0.130^{* * *}$ & $-0.126^{* * *}$ \\
\hline & $(0.00859)$ & $(0.00775)$ & $(0.00792)$ & $(0.00725)$ & $(0.00789)$ & $(0.00871)$ \\
\hline \multirow[t]{2}{*}{ license } & $0.00714^{*}$ & $0.0196^{* * *}$ & $0.0150^{* *}$ & 0.0145 & 0.0128 & $0.0473^{* * *}$ \\
\hline & $(0.00391)$ & $(0.00597)$ & $(0.00733)$ & $(0.00876)$ & $(0.0105)$ & $(0.00632)$ \\
\hline \multirow{2}{*}{ license $\times$ black } & $-0.0195^{*}$ & $-0.0355^{* * * *}$ & -0.00788 & -0.0121 & -0.00897 & $-0.0385^{*}$ \\
\hline & $(0.0103)$ & $(0.0121)$ & $(0.0134)$ & $(0.0238)$ & $(0.0269)$ & $(0.0207)$ \\
\hline \multirow{2}{*}{ felony ban $\times$ BTB } & 0.00684 & 0.00302 & -0.0113 & -0.0208 & -0.00750 & 0.0293 \\
\hline & $(0.00960)$ & $(0.0101)$ & $(0.0122)$ & $(0.0144)$ & $(0.0235)$ & $(0.0277)$ \\
\hline \multirow{2}{*}{ felony ban $\times$ BTB $\times$ black } & $0.126^{* * *}$ & $0.138^{* * *}$ & $0.194^{* * *}$ & $0.130^{* * *}$ & $0.176^{* * *}$ & $0.190^{* * *}$ \\
\hline & $(0.0221)$ & $(0.0336)$ & $(0.0293)$ & $(0.0405)$ & $(0.0451)$ & $(0.0496)$ \\
\hline \multirow[t]{2}{*}{ felony ban $\times$ nonBTB } & -0.0133 & $-0.0266^{* *}$ & $-0.0266^{*}$ & -0.0249 & -0.0251 & -0.0179 \\
\hline & $(0.0124)$ & $(0.0127)$ & $(0.0138)$ & $(0.0153)$ & $(0.0152)$ & $(0.0140)$ \\
\hline \multirow[t]{2}{*}{ felony ban $\times$ nonBTB $\times$ black } & -0.00150 & 0.0218 & 0.0298 & 0.0323 & 0.0516 & $0.109^{* *}$ \\
\hline & $(0.0197)$ & $(0.0246)$ & $(0.0281)$ & $(0.0443)$ & $(0.0441)$ & $(0.0496)$ \\
\hline \multirow[t]{2}{*}{ Constant } & $1.693^{* * *}$ & $1.690^{* * *}$ & $1.694^{* * *}$ & $1.695^{* * *}$ & $1.695^{* * *}$ & $1.700^{* * * *}$ \\
\hline & $(0.0365)$ & $(0.0370)$ & $(0.0369)$ & $(0.0369)$ & $(0.0369)$ & $(0.0369)$ \\
\hline Observations & 52,034 & 52,034 & 52,034 & 52,034 & 52,034 & 52,034 \\
\hline R-squared & 0.427 & 0.427 & 0.427 & 0.427 & 0.427 & 0.428 \\
\hline
\end{tabular}

Data Source: CPS monthly survey 2015; American Bar Association Database.

Notes: Dependent variable is the log of hourly wage. In Column 1 to 5 , the 'license' variable is based on the corresponding cutoff specified at the top of the table (a state-specific 6 digit-level occupation requires a license if $x \%$ or more respondents in that cell reported having a license in CPS). 'Felony ban' indicator equals 1 if 'license' equals 1 . Ban-the-Box (BTB) states refer to state implemented statewide BTB law in the public or private sector. They include California, Colorado, Connecticut, DC, Hawaii, Massachusetts, Minnesota, and New Mexico. The sample is restricted to male workers who are white or black. Hispanics and workers of other races are excluded.

All regressions include month, state, and 6-digit occupation fixed effects. Individual controls include a quadratic in age, education levels, union status, a government worker indicator, a self-employed indicator, a service worker indicator. In addition, we include indicator for 'certification.' The sample is restricted to respondents aged 18-64 with hourly wages on the main job between $\$ 5$ and $\$ 100$. All regressions are weighted by sampling weight.

Standard errors are clustered at the state level. ${ }^{* * *}, * *, *$ correspond to $1 \%, 5 \%, 10 \%$ significance level, respectively. 


\section{Appendix: For Online Publication}

\section{A.1 Construction of Felony Data}

We assembled a new dataset from the Criminal Justice Section of the American Bar Association (ABA) in May 2016. ${ }^{49}$ The database contains license restrictions that felons face when applying for an occupational license in each occupation and in each state of the US.

After integrating all data entries into one spreadsheet, for each legal restriction, we observe four variables that are crucial to our analysis: 1) the state enacting the law, 2) description on restrictions (law title), 3) duration of the restrictions, and 4) whether the restriction is mandatory or discretionary. In Figure A1 we provide a screenshot of the first few rows in our raw data.

Figure A1: Screenshot of ABA Database on Felony Restrictions
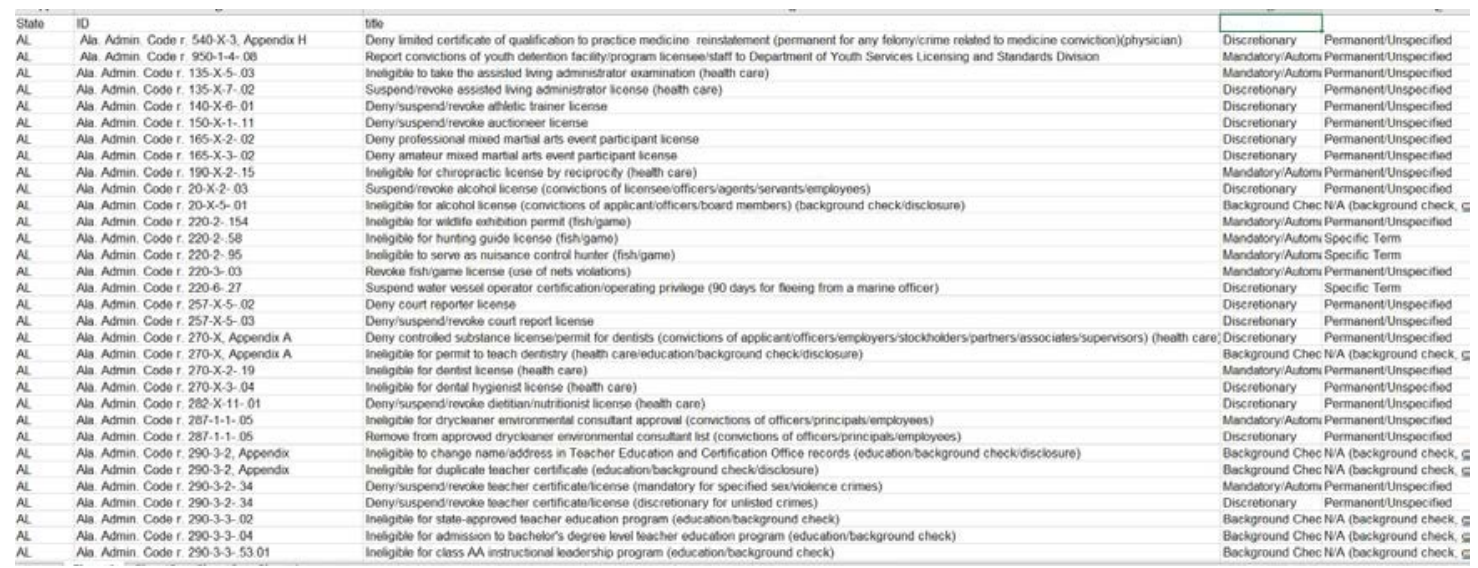

Note: The database includes the title, whether the law is mandatory and permanent. We define 'felony ban' occupations as the licensed professions with mandatory and permanent restrictions against felons. An occupation can have multiple law citations, and we use the most restrictive one.

In total, the database contains 16,343 occupational licensing restrictions that apply to individuals with criminal convictions. To identify whether the individuals in the SIPP work in licensed professions with a felony ban, we need to determine the corresponding professions which the felony restrictions apply. In Figure A2, we demonstrate how we

\footnotetext{
${ }^{49}$ We accessed the database through http://abacollateralconsequences.org/. This link was shut down, and the database later migrated to https://niccc.nationalreentryresourcecenter.org/ with more recent information.
} 
Figure A2: Relate Law Citations to Occupation Code

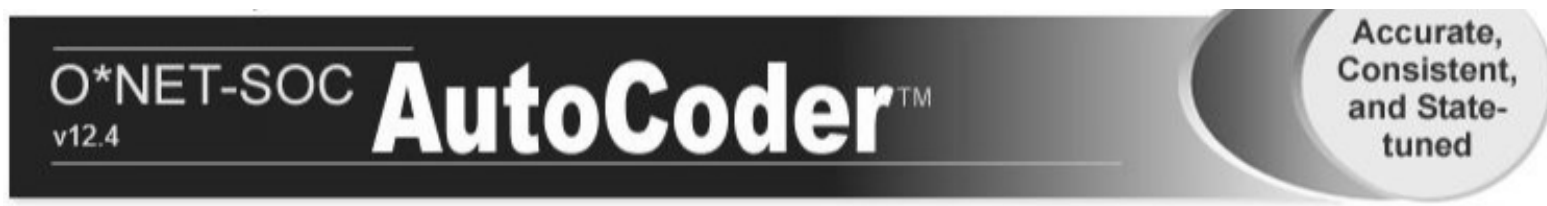

\begin{tabular}{|l|}
\hline Themetic $^{\mathrm{TM}}$ Search \\
\hline Job Title \\
\hline Job Description \\
\hline $\begin{array}{l}\text { Ineligible for mortgage } \\
\text { loan originator license } \\
\text { (permanent for felonies }\end{array}$ \\
\begin{tabular}{l} 
Set Supplementary Inputs \\
\hline Search clear \\
\hline
\end{tabular} \\
\hline
\end{tabular}

\begin{tabular}{|c|c|c|c|c|}
\hline ONET 2016-8 & NEC & SOC 2010 & & \\
\hline Code & & Title & Score & \\
\hline $13-2072.00$ & Loan & Dfficers & 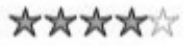 & 82 \\
\hline $11-3031.02$ & $\begin{array}{l}\text { Finar } \\
\text { Depa }\end{array}$ & $\begin{array}{l}\text { ial Managers, Branch or } \\
\text { tment }\end{array}$ & thistith & 52 \\
\hline $43-4131.00$ & Loan & nterviewers and Clerks & 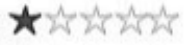 & 49 \\
\hline $41-3031.02$ & Sale: & Agents, Financial Services & 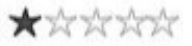 & 46 \\
\hline $13-2061.00$ & Finar & ial Examiners & $x+x^{2} x x^{2}$ & 45 \\
\hline
\end{tabular}

Note: We put each law description to "Job Description". The program will then report the relevant occupations, with matching quality scores. We take the one with the highest quality score.

utilize a public online platform called the SOC AutoCoder, which is hosted by the US Department of Labor. We enter the law description of each felony restriction into the 'Job Description' box of the SOC AutoCoder, as shown in Figure A2. In this example, the law title states that the rule renders felons "ineligible for mortgage originators license." We find the most likely occupation covered by this law by feeding the expression "ineligible for mortgage originators license" into the SOC AutoCoder and recording the occupation with the highest match quality. The best match in this case is "Loan Officers" (6-digit SOC code "13-2072"). We created a web-scraping algorithm to automate the process since the O*net server blocks access if a given IP address conducts a high volume of searches in rapid succession. 


\section{A.2 Coding occupations with multiple restrictions}

After obtaining the occupation codes for each legal restriction, we find that the same state-occupation may have multiple legal restrictions. For example, Alabama imposes the following five different felony restrictions for elementary school teachers:

Table A1: An example with multiple restrictions in the same state-occupation

\begin{tabular}{l|l}
\hline \hline Statute identification \& Description & \\
\hline Ala. Admin. Code r. 290-3-2, Appendix & $\begin{array}{l}\text { Ineligible for duplicate teacher certifi- } \\
\text { cate } \\
\text { Deny/suspend/revoke teacher cer- } \\
\text { tificate/license (mandatory for speci- } \\
\text { fied sex/violence crimes) } \\
\text { Deny/suspend/revoke teacher cer- } \\
\text { tificate/license (discretionary for un- } \\
\text { listed crimes) } \\
\text { Ineligible for state-approved teacher } \\
\text { education program } \\
\text { Ineligible for admission to bachelor's } \\
\text { degree level teacher education pro- } \\
\text { gram }\end{array}$ \\
Ala. Admin. Code r. 290-3-3-.02 & Ala. Admin. Code r. 290-3-3-.04
\end{tabular}

To determine the nature of the felony bans in the regression, we code our felony variable to correspond to the most severe punishment in terms of the duration and whether discretion is allowed. We take 'permanent and mandatory' to be the most severe followed by 'temporary and mandatory'. The least binding possibility is a discretionary restriction.

As an example to illustrate in Table A1, we code the elementary school teachers in Alabama as one with a permanent and mandatory ban since 'Deny/suspend/revoke teacher certificate/license (mandatory for specified sex/violence crimes)' is the most severe consequence. This potentially biases us against finding different effects between the most severe category (i.e., permanent ban) and the least severe category (i.e., the general license variable defined by the 50-50 threshold). 


\section{A.3 Supplementary maps of licensing data}

Figure A3: The percentage of workers in licensed occupations with felony bans

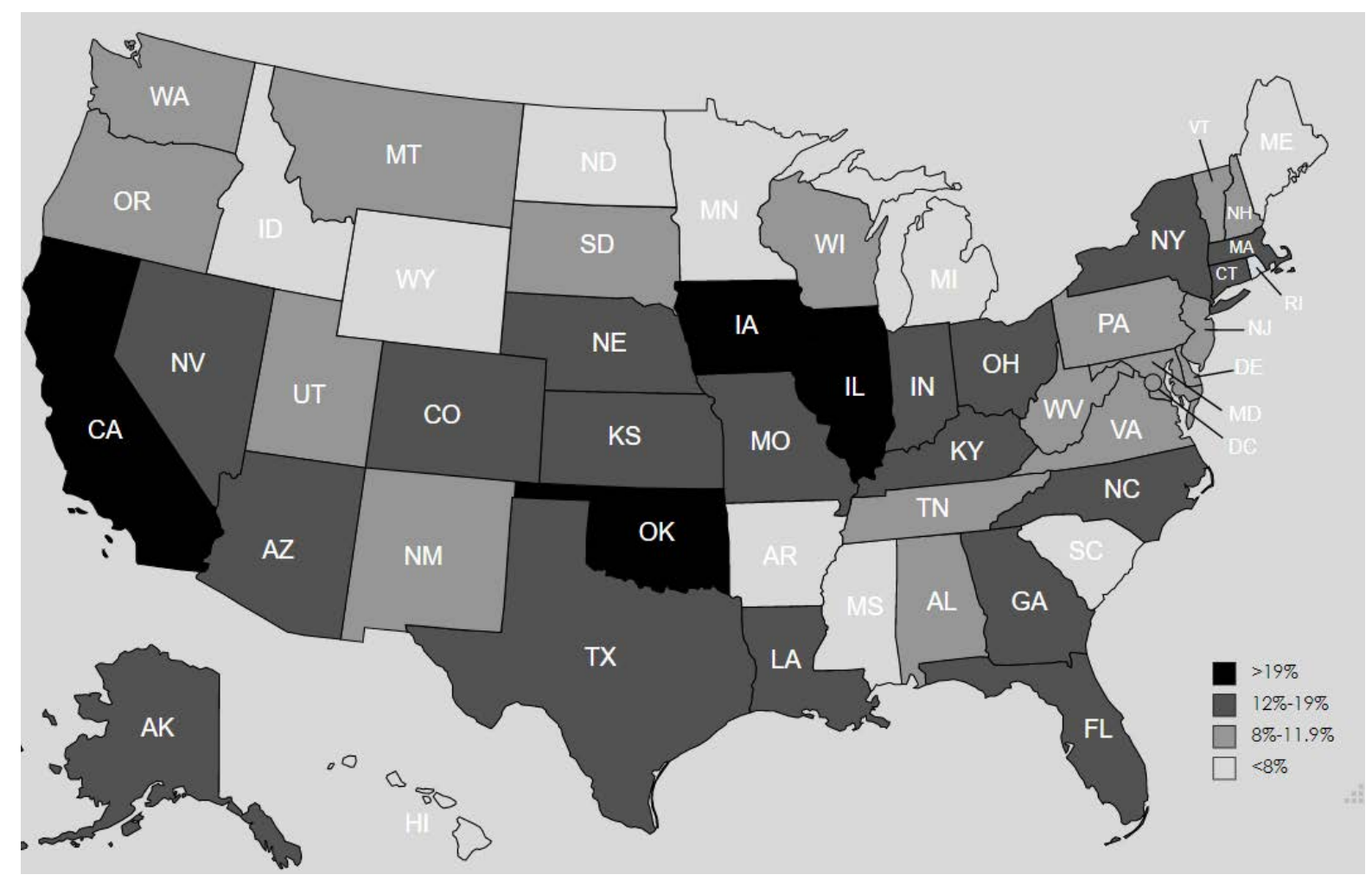

Note: This map depicts cross-sectional variation in felony restriction based on the American Bar Association Database (2016). The states shaded in with darker color have more percent of workers who work in licensed occupations with felony bans. 


\section{Figure A4: Number of Professions with a License of any kind}

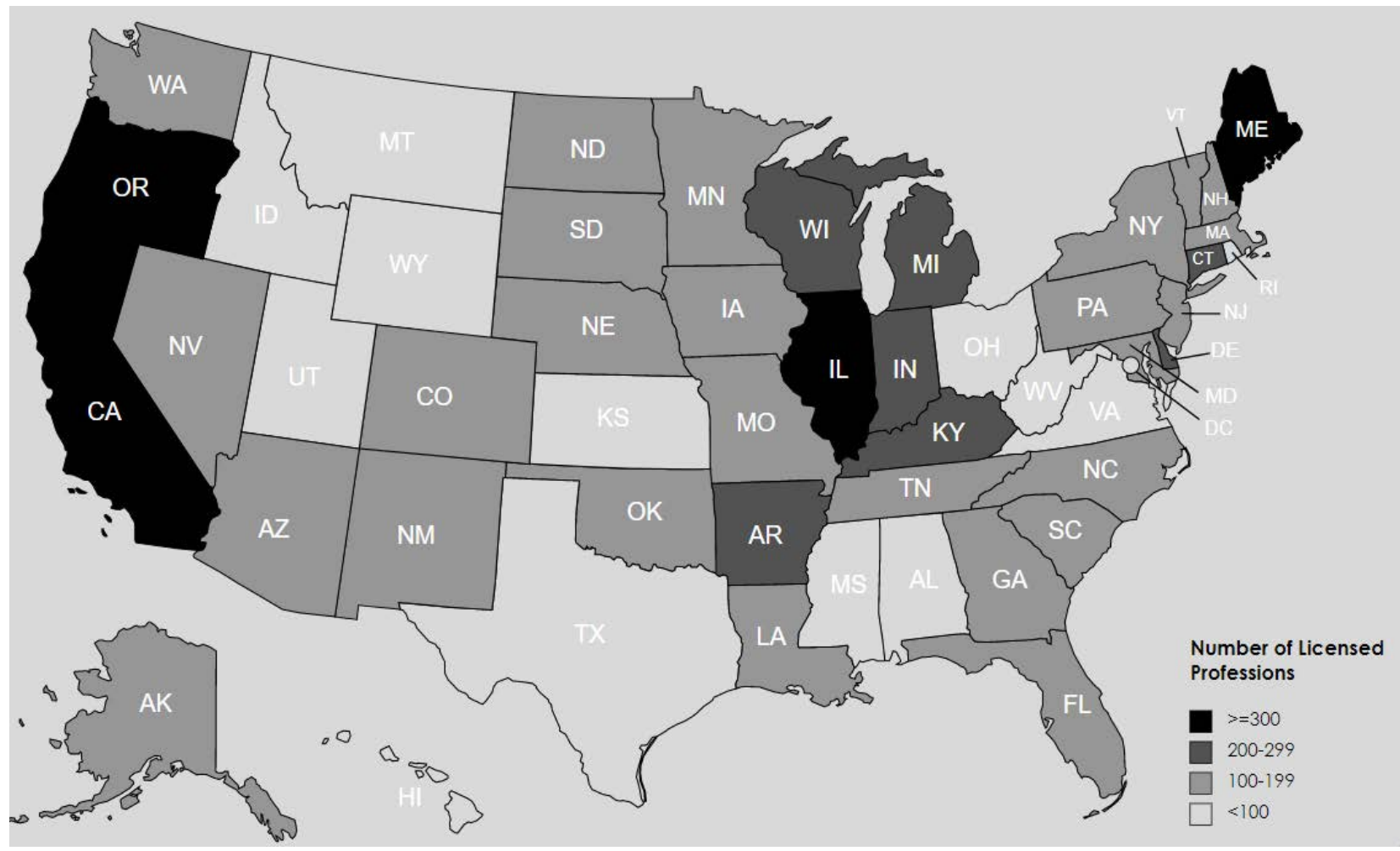

Note: This map depicts the number of occupations in each state that has an occupational license requirement. The dataset is generated using the topical module on licensing from Wave 13 of Survey of Income and Program Participation. We code a state-occupation pair as licensed if $>50 \%$ of workers in that state-occupation pair report having a license. The states shaded in with darker color have more licensed professions. 
Table A2: Applying 50\% threshold rule to 5 largest universally licensed occupations

\begin{tabular}{lccc}
\hline \hline & \multicolumn{2}{c}{ Percent licensed } & Improvement (p.p.) \\
\cline { 2 - 3 } Occupation & Individual & $50-50$ rule & \\
\hline Secondary school teachers & $74 \%$ & $98 \%$ & +24 \\
Elementary and middle school teachers & $71 \%$ & $85 \%$ & +14 \\
Lawyers & $62 \%$ & $73 \%$ & +11 \\
Registered Nurse & $60 \%$ & $64 \%$ & +4 \\
Physicians & $72 \%$ & $72 \%$ & +0 \\
\hline \hline
\end{tabular}

Note: This table compares the percent of licensed workers in universal licensed professions using the self-reported license status to the percent licensed using the $50 \%$ threshold rule. The final column records the improvement in the licensing coverage coming from the $50 \%$ threshold relative to the license self-reports of workers. 


\section{A.4 Supplementary Results}

Table B1: Results where 'felony ban' includes temporary restrictions

\begin{tabular}{|c|c|c|c|c|c|}
\hline & (1) & (2) & (3) & $(4)$ & (5) \\
\hline & \multicolumn{5}{|c|}{ Define a licensed occupation if percent of licensed at least: } \\
\hline & $10 \%$ & $20 \%$ & $30 \%$ & $40 \%$ & $50 \%$ \\
\hline \multirow[t]{2}{*}{ black } & $-0.126^{* * *}$ & $-0.122^{* * *}$ & $-0.115^{* * *}$ & $-0.110^{* * *}$ & $-0.108^{* * *}$ \\
\hline & $(0.0215)$ & $(0.0212)$ & $(0.0175)$ & $(0.0179)$ & $(0.0179)$ \\
\hline \multirow{2}{*}{ license } & 0.0157 & 0.00221 & 0.00694 & 0.0108 & 0.0252 \\
\hline & $(0.0168)$ & $(0.0177)$ & $(0.0201)$ & $(0.0230)$ & $(0.0228)$ \\
\hline \multirow[t]{2}{*}{ license $\times$ black } & $0.0761^{*}$ & 0.0535 & 0.0460 & -0.00294 & -0.0195 \\
\hline & $(0.0439)$ & $(0.0428)$ & $(0.0574)$ & $(0.0658)$ & $(0.0733)$ \\
\hline \multirow[t]{2}{*}{ felony ban $\times$ BTB } & $0.0724^{* *}$ & $0.0614^{* *}$ & $0.0726^{*}$ & $0.0909^{* *}$ & 0.0806 \\
\hline & $(0.0310)$ & $(0.0291)$ & $(0.0377)$ & $(0.0428)$ & $(0.0497)$ \\
\hline \multirow{2}{*}{ felony ban $\times$ BTB $\times$ black } & $0.204^{* * *}$ & $0.233^{* * *}$ & $0.316^{* * *}$ & $0.344^{* * *}$ & $0.332^{* * *}$ \\
\hline & $(0.0503)$ & $(0.0491)$ & (0.0749) & (0.0797) & $(0.0886)$ \\
\hline \multirow[t]{2}{*}{ felony ban $\times$ nonBTB } & 0.0251 & 0.0214 & 0.00182 & 0.0187 & 0.0240 \\
\hline & $(0.0291)$ & $(0.0260)$ & $(0.0284)$ & $(0.0341)$ & $(0.0334)$ \\
\hline \multirow[t]{2}{*}{ felony ban $\times$ nonBTB $\times$ black } & 0.0112 & 0.0714 & 0.104 & 0.164 & $0.309^{* *}$ \\
\hline & $(0.0560)$ & $(0.0550)$ & $(0.0904)$ & (0.0990) & $(0.123)$ \\
\hline \multirow[t]{2}{*}{ Constant } & $2.106^{* * *}$ & $2.106^{* * *}$ & $2.110^{* * *}$ & $2.111^{* * *}$ & $2.109^{* * *}$ \\
\hline & $(0.0772)$ & $(0.0765)$ & $(0.0756)$ & $(0.0751)$ & $(0.0756)$ \\
\hline Observations & 30,256 & 30,256 & 30,256 & 30,256 & 30,256 \\
\hline R-squared & 0.561 & 0.561 & 0.561 & 0.561 & 0.561 \\
\hline
\end{tabular}

Data Source: Wave 13 of SIPP Panel 2008; American Bar Association Database.

Notes: Dependent variable is the log of hourly wage. 'Felony ban' indicator equals 1 only if 'license' equals 1 . Different from the main equation, the regressions here define 'felony ban' equals 1 for mandatory felony restrictions of any duration. Ban-the-Box (BTB) states refer to state implemented statewide BTB law in the public or private sector. They include California, Colorado, Connecticut, DC, Hawaii, Massachusetts, Minnesota, and New Mexico. The sample is restricted to male workers who are white or black. Hispanics and workers of other races are excluded.

All regressions include month, state, and 6-digit occupation fixed effects. Individual controls include a quadratic in age, education levels, union status, a government worker indicator, a self-employed indicator, a service worker indicator. In addition, we include indicators for 'certification', 'license not required for jobs.' The sample is restricted to respondents aged 18-64 with hourly wages on the main job between $\$ 5$ and $\$ 100$. Observations with imputed wages and license status are dropped. All regressions are weighted by sampling weight. Standard errors are clustered at the state level. ***,

**, * correspond to $1 \%, 5 \%, 10 \%$ significance level, respectively. 
Table B2: Results using one observation per respondent and 50\% threshold

\begin{tabular}{|c|c|c|c|c|c|c|}
\hline & $\begin{array}{c}(1) \\
\text { Base }\end{array}$ & $\begin{array}{c}(2) \\
\text { Race }\end{array}$ & $\begin{array}{l}\text { (3) } \\
\text { Ban }\end{array}$ & $\begin{array}{c}(4) \\
\text { firm size }\end{array}$ & $\begin{array}{c}\text { (5) } \\
\text { firm size }\end{array}$ & $\begin{array}{c}(6) \\
\text { BTB Laws } \\
\end{array}$ \\
\hline black & $\begin{array}{c}-0.0936^{* * *} \\
(0.0195)\end{array}$ & $\begin{array}{c}-0.107^{* * *} \\
(0.0201)\end{array}$ & $\begin{array}{c}-0.106^{* * *} \\
(0.0200)\end{array}$ & $\begin{array}{c}-0.126^{* * *} \\
(0.0236)\end{array}$ & $\begin{array}{c}-0.0971^{* * *} \\
(0.0299)\end{array}$ & $\begin{array}{c}-0.107^{* * *} \\
(0.0201)\end{array}$ \\
\hline license & $\begin{array}{l}0.0437^{* *} \\
(0.0205)\end{array}$ & $\begin{array}{c}0.0311 \\
(0.0197)\end{array}$ & $\begin{array}{c}0.0203 \\
(0.0230)\end{array}$ & $\begin{array}{c}0.0342 \\
(0.0304)\end{array}$ & $\begin{array}{l}0.00607 \\
(0.0337)\end{array}$ & $\begin{array}{c}0.0199 \\
(0.0231)\end{array}$ \\
\hline license $\times$ black & & $\begin{array}{c}0.156^{* *} \\
(0.0643)\end{array}$ & $\begin{array}{c}0.102 \\
(0.0704)\end{array}$ & $\begin{array}{l}0.0864 \\
(0.106)\end{array}$ & $\begin{array}{c}0.195^{* *} \\
(0.0925)\end{array}$ & $\begin{array}{c}0.102 \\
(0.0706)\end{array}$ \\
\hline felony ban & & & $\begin{array}{c}0.0485 \\
(0.0343)\end{array}$ & $\begin{array}{c}0.0195 \\
(0.0479)\end{array}$ & $\begin{array}{l}0.106^{* *} \\
(0.0523)\end{array}$ & \\
\hline felony ban $\times$ black & & & $\begin{array}{c}0.126 \\
(0.122)\end{array}$ & $\begin{array}{l}0.248^{* *} \\
(0.121)\end{array}$ & $\begin{array}{c}-0.124 \\
(0.184)\end{array}$ & \\
\hline felony ban $\times$ BTB & & & & & & $\begin{array}{c}0.0663 \\
(0.0550)\end{array}$ \\
\hline felony ban $\times$ BTB $\times$ black & & & & & & $\begin{array}{c}0.307^{* * *} \\
(0.100)\end{array}$ \\
\hline felony ban $\times$ nonBTB & & & & & & $\begin{array}{c}0.0422 \\
(0.0355)\end{array}$ \\
\hline felony ban $\times$ nonBTB $\times$ black & & & & & & $\begin{array}{l}0.0390 \\
(0.125)\end{array}$ \\
\hline Constant & $\begin{array}{l}2.090^{* * *} \\
(0.0880)\end{array}$ & $\begin{array}{l}2.089^{* * *} \\
(0.0877)\end{array}$ & $\begin{array}{l}2.091^{* * *} \\
(0.0868)\end{array}$ & $\begin{array}{c}2.166^{* * *} \\
(0.101)\end{array}$ & $\begin{array}{c}2.124^{* * *} \\
(0.158)\end{array}$ & $\begin{array}{l}2.090^{* * *} \\
(0.0871)\end{array}$ \\
\hline Observations & 7,510 & 7,510 & 7,510 & 4,479 & 3,031 & 7,510 \\
\hline R-squared & 0.563 & 0.563 & 0.564 & 0.563 & 0.612 & 0.564 \\
\hline
\end{tabular}

Data Source: Wave 13 of SIPP Panel 2008; American Bar Association Database.

Notes: Dependent variable is the log of hourly wage. The 'license' variable is based on the 50-50 rule (a state-specific 6 digit-level occupation requires a license if $50 \%$ or more respondents in that cell reported having a license in SIPP). 'Felony ban' indicator equals 1 only if 'license' equals 1 . Ban-the-Box (BTB) states refer to state implemented statewide BTB law in the public or private sector. They include California, Colorado, Connecticut, DC, Hawaii, Massachusetts, Minnesota, and New Mexico. The sample is restricted to male workers who are white or black. Hispanics and workers of other races are excluded. All regressions include month, state, and 6-digit occupation fixed effects. Individual controls include a quadratic in age, education levels, union status, a government worker indicator, a self-employed indicator, a service worker indicator. In addition, we include indicators for 'certification' and 'license not required for jobs.' The sample is restricted to respondents aged 18-64 with hourly wages on the main job between $\$ 5$ and $\$ 100$ in the last reference month. Observations with imputed wages and license status are dropped. All regressions are weighted by sampling weight. Standard errors are clustered at the state level. ${ }^{* * *},{ }^{* *},{ }^{*}$ correspond to $1 \%, 5 \%, 10 \%$ significance level, respectively. 
Table B3: Test for difference in the license premiums in public versus private sector

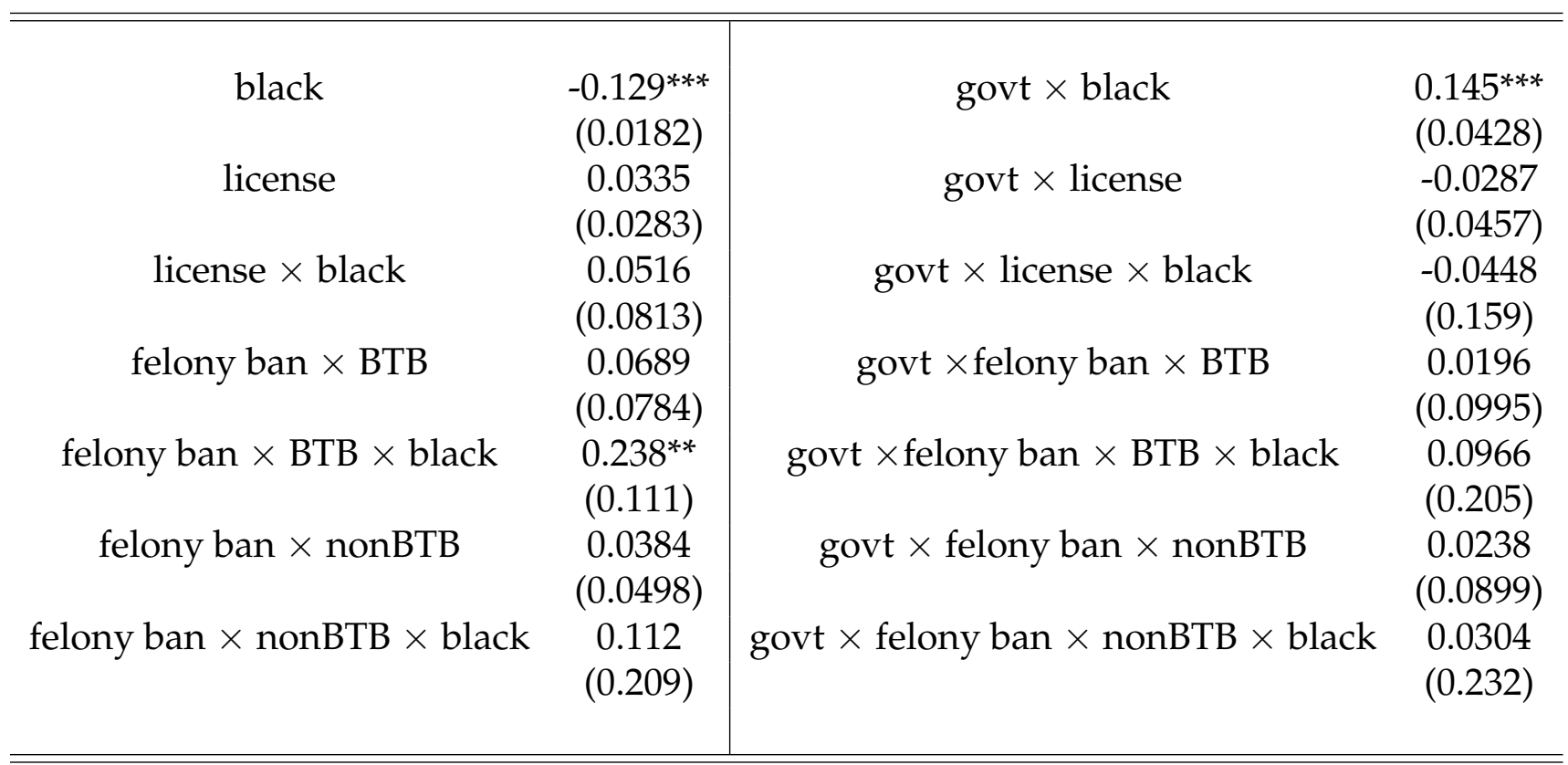

Data Source: Wave 13 of SIPP Panel 2008; American Bar Association Database.

Note: All coefficients are obtained from the same fifth differences model (with the full set of control variables in the main specification), where we interact the race and license variables by a government worker indicator. The coefficient of 'govt $\times$ felony ban $\times \mathrm{BTB} \times$ ' indicates the ban premium in BTB states for black men in the public sector is higher than that in the private sector, but the difference is not statistically significant.

Dependent variable is the log of hourly wage. 'Felony ban' indicator equals 1 only if 'license' equals 1 . Ban-the-Box (BTB) states refer to state implemented statewide BTB law in the public or private sector. They include California, Colorado, Connecticut, DC, Hawaii, Massachusetts, Minnesota, and New Mexico. The sample is restricted to male workers who are white or black. Hispanics and workers of other races are excluded. All regressions include month, state, and 6-digit occupation fixed effects. Individual controls include a quadratic in age, education levels, union status, a government worker indicator, a self-employed indicator, a service worker indicator. In addition, we include indicators for 'certification', 'license not required for jobs.' The sample is restricted to respondents aged 18-64 with hourly wages on the main job between $\$ 5$ and $\$ 100$. Observations with imputed wages and license status are dropped. All regressions are weighted by sampling weight. Standard errors are clustered at the state level. $* * *, * * *$ correspond to $1 \%, 5 \%, 10 \%$ significance level, respectively. 


\section{Table B4: Test for policy endogeneity of felony bans}

\begin{tabular}{|c|c|c|c|c|c|c|c|c|c|}
\hline \multirow[t]{2}{*}{ Outcome } & \multicolumn{3}{|c|}{$\begin{array}{c}Y_{i}=1 \text { if any license license }=0 \\
\text { (All state-occupations) }\end{array}$} & \multicolumn{3}{|c|}{$\begin{array}{c}Y_{i}=1 \text { if license } \mathrm{w} / \text { felony ban } \\
\text { (All state-occupations) }\end{array}$} & \multicolumn{3}{|c|}{$\begin{array}{l}Y_{i}=1 \text { if license } \mathrm{w} / \text { felony ban } \\
\text { (Licensed state-occupations) }\end{array}$} \\
\hline & $(1)$ & $(2)$ & $(3)$ & $(4)$ & (5) & $(6)$ & $(7)$ & $(8)$ & (9) \\
\hline \multicolumn{10}{|l|}{ State characteristics: } \\
\hline minimum wage (\$) & $\begin{array}{l}-0.00156 \\
(0.00236)\end{array}$ & $\begin{array}{l}-0.00113 \\
(0.00247)\end{array}$ & -0.00750 & $\begin{array}{l}-0.00258 \\
(0.00161)\end{array}$ & $\begin{array}{l}-0.00251^{*} \\
(0.00148)\end{array}$ & -0.0345 & $\begin{array}{l}-0.0151^{*} \\
(0.00879)\end{array}$ & $\begin{array}{l}-0.00964 \\
(0.00850)\end{array}$ & -0.0551 \\
\hline Right-to-Work & $\begin{array}{c}0.0357^{* * *} \\
(0.0131)\end{array}$ & $\begin{array}{l}0.0268^{*} \\
(0.0147)\end{array}$ & 0.0387 & $\begin{array}{l}-0.00229 \\
(0.00971)\end{array}$ & $\begin{array}{l}-0.00124 \\
(0.00996)\end{array}$ & -0.00370 & $\begin{array}{l}-0.0367 \\
(0.0609)\end{array}$ & $\begin{array}{l}-0.0176 \\
(0.0867)\end{array}$ & -0.0216 \\
\hline republican vote (\%) & $\begin{array}{l}-0.109 \\
(0.0876)\end{array}$ & $\begin{array}{l}-0.119 \\
(0.0813)\end{array}$ & -0.0318 & $\begin{array}{c}0.0280 \\
(0.0432)\end{array}$ & $\begin{array}{r}-0.00149 \\
(0.0436)\end{array}$ & -0.000825 & $\begin{array}{c}0.199 \\
(0.283)\end{array}$ & $\begin{array}{l}0.0687 \\
(0.390)\end{array}$ & 0.0151 \\
\hline \multicolumn{10}{|c|}{ State-by-occupation characteristics: } \\
\hline black & $\begin{array}{c}-0.0753^{* * *} \\
(0.0130)\end{array}$ & $\begin{array}{c}-0.0712^{* * *} \\
(0.0180)\end{array}$ & -0.0554 & $\begin{array}{c}-0.0199^{* * *} \\
(0.00708)\end{array}$ & $\begin{array}{c}-0.0283^{* * *} \\
(0.00935)\end{array}$ & -0.0454 & $\begin{array}{l}-0.0787 \\
(0.0718)\end{array}$ & $\begin{array}{l}-0.154 \\
(0.120)\end{array}$ & -0.0822 \\
\hline age & $\begin{array}{l}0.000878^{*} \\
(0.000456)\end{array}$ & $\begin{array}{c}0.000528 \\
(0.000546)\end{array}$ & 0.0170 & $\begin{array}{c}1.51 \mathrm{e}-05 \\
(0.000226)\end{array}$ & $\begin{array}{c}3.07 \mathrm{e}-05 \\
(0.000235)\end{array}$ & 0.00204 & $\begin{array}{r}-0.000998 \\
(0.00159)\end{array}$ & $\begin{array}{l}0.000663 \\
(0.00205)\end{array}$ & 0.0169 \\
\hline hs & $\begin{array}{l}0.0519^{* * *} \\
(0.0178)\end{array}$ & $\begin{array}{l}0.0378^{* *} \\
(0.0186)\end{array}$ & 0.0417 & $\begin{array}{c}0.00511 \\
(0.00443)\end{array}$ & $\begin{array}{c}0.00143 \\
(0.00352)\end{array}$ & 0.00325 & $\begin{array}{c}0.0409 \\
(0.0819)\end{array}$ & $\begin{array}{l}-0.0354 \\
(0.104)\end{array}$ & -0.0277 \\
\hline somecollege & $\begin{array}{l}0.101^{* * *} \\
(0.0175)\end{array}$ & $\begin{array}{c}0.0682^{* * *} \\
(0.0196)\end{array}$ & 0.0849 & $\begin{array}{l}0.0211^{* * *} \\
(0.00522)\end{array}$ & $\begin{array}{l}0.00829^{* *} \\
(0.00410)\end{array}$ & 0.0213 & $\begin{array}{c}0.124 \\
(0.0833)\end{array}$ & $\begin{array}{r}-0.0883 \\
(0.117)\end{array}$ & -0.0974 \\
\hline college & $\begin{array}{c}0.0893^{* * *} \\
(0.0214)\end{array}$ & $\begin{array}{c}0.0406 \\
(0.0290)\end{array}$ & 0.0453 & $\begin{array}{l}0.0205^{* * *} \\
(0.00534)\end{array}$ & $\begin{array}{l}-0.00309 \\
(0.00756)\end{array}$ & -0.00713 & $\begin{array}{c}0.106 \\
(0.0926)\end{array}$ & $\begin{array}{l}-0.117 \\
(0.138)\end{array}$ & -0.114 \\
\hline postgrad & $\begin{array}{l}0.161^{* * *} \\
(0.0297)\end{array}$ & $\begin{array}{c}0.0245 \\
(0.0359)\end{array}$ & 0.0213 & $\begin{array}{c}0.0766^{* * *} \\
(0.0136)\end{array}$ & $\begin{array}{c}0.0128 \\
(0.0129)\end{array}$ & 0.0230 & $\begin{array}{l}0.261^{* *} \\
(0.0984)\end{array}$ & $\begin{array}{l}-0.126 \\
(0.142)\end{array}$ & -0.119 \\
\hline union & $\begin{array}{l}0.119^{* * *} \\
(0.0220)\end{array}$ & $\begin{array}{c}0.0263 \\
(0.0200)\end{array}$ & 0.0238 & $\begin{array}{l}0.0355^{* * *} \\
(0.00912)\end{array}$ & $\begin{array}{l}0.00854 \\
(0.0111)\end{array}$ & 0.0159 & $\begin{array}{l}0.0340 \\
(0.0441)\end{array}$ & $\begin{array}{c}0.0379 \\
(0.0751)\end{array}$ & 0.0362 \\
\hline govt & $\begin{array}{l}0.133^{* * *} \\
(0.0155)\end{array}$ & $\begin{array}{l}0.0453^{* *} \\
(0.0194)\end{array}$ & 0.0463 & $\begin{array}{c}0.0369^{* * *} \\
(0.0103)\end{array}$ & $\begin{array}{c}-0.00134 \\
(0.00969)\end{array}$ & -0.00282 & $\begin{array}{c}0.0655 \\
(0.0433)\end{array}$ & $\begin{array}{c}-0.00970 \\
(0.0654)\end{array}$ & -0.0106 \\
\hline self_emp & $\begin{array}{l}0.0730^{*} \\
(0.0400)\end{array}$ & $\begin{array}{c}0.0290 \\
(0.0374)\end{array}$ & 0.0130 & $\begin{array}{c}-0.0123 \\
(0.0151)\end{array}$ & $\begin{array}{l}-0.0126 \\
(0.0138)\end{array}$ & -0.0117 & $\begin{array}{c}-0.157^{* *} \\
(0.0721)\end{array}$ & $\begin{array}{c}-0.0877 \\
(0.0913)\end{array}$ & -0.0411 \\
\hline service & $\begin{array}{l}0.105^{* * *} \\
(0.0131)\end{array}$ & $\begin{array}{c}0.0391^{* * *} \\
(0.0145)\end{array}$ & 0.0527 & $\begin{array}{l}0.0367^{* * *} \\
(0.00647)\end{array}$ & $\begin{array}{c}0.00729 \\
(0.00774)\end{array}$ & 0.0203 & $\begin{array}{l}0.116^{* * *} \\
(0.0408)\end{array}$ & $\begin{array}{c}0.127 \\
(0.0918)\end{array}$ & 0.149 \\
\hline eng & $\begin{array}{l}0.00546 \\
(0.0158)\end{array}$ & $\begin{array}{l}0.00988 \\
(0.0155)\end{array}$ & 0.0116 & $\begin{array}{c}-0.00288 \\
(0.00582)\end{array}$ & $\begin{array}{c}-0.00350 \\
(0.00635)\end{array}$ & -0.00851 & $\begin{array}{c}-0.0318 \\
(0.0391)\end{array}$ & $\begin{array}{c}-0.0490 \\
(0.0616)\end{array}$ & -0.0461 \\
\hline math & $\begin{array}{c}-0.0118 \\
(0.0163)\end{array}$ & $\begin{array}{l}0.00715 \\
(0.0166)\end{array}$ & 0.00918 & $\begin{array}{c}-0.00592 \\
(0.00689)\end{array}$ & $\begin{array}{c}0.00396 \\
(0.00777)\end{array}$ & 0.0105 & $\begin{array}{r}-0.00240 \\
(0.0578)\end{array}$ & $\begin{array}{c}0.0157 \\
(0.0795)\end{array}$ & 0.0169 \\
\hline sci & $\begin{array}{c}0.0125 \\
(0.0194)\end{array}$ & $\begin{array}{c}0.000470 \\
(0.0180)\end{array}$ & 0.000607 & $\begin{array}{c}-0.000171 \\
(0.00846)\end{array}$ & $\begin{array}{c}-0.00733 \\
(0.00915)\end{array}$ & -0.0195 & $\begin{array}{c}-0.0249 \\
(0.0526)\end{array}$ & $\begin{array}{l}-0.0640 \\
(0.0687)\end{array}$ & -0.0700 \\
\hline person & $\begin{array}{l}-0.0950^{*} \\
(0.0557)\end{array}$ & $\begin{array}{c}-0.0893 \\
(0.0615)\end{array}$ & -0.0224 & $\begin{array}{l}-0.0287^{*} \\
(0.0145)\end{array}$ & $\begin{array}{l}-0.0289 \\
(0.0242)\end{array}$ & -0.0150 & $\begin{array}{l}-0.0167 \\
(0.210)\end{array}$ & $\begin{array}{c}0.511 \\
(0.504)\end{array}$ & 0.0836 \\
\hline Observations & 4,187 & 4,187 & 4,187 & 4,187 & 4,187 & 4,187 & 576 & 576 & 576 \\
\hline R-squared & 0.082 & 0.348 & 0.348 & 0.043 & 0.268 & 0.268 & 0.075 & 0.446 & 0.446 \\
\hline Occupation FE & & $x$ & $x$ & & $x$ & $x$ & & $x$ & $x$ \\
\hline Standardized Coefficient & & & $\mathrm{X}$ & & & $\mathrm{X}$ & & & $\mathrm{X}$ \\
\hline
\end{tabular}

Note: Minimum wage requirement (in dollar) by state in 2013 is obtained from the website of the US Department of Labor. Standard errors are clustered at the state level. 
Table B5: Results Excluding Cross-border Commuters using 50\% threshold

\begin{tabular}{lcc}
\hline \hline & $(1)$ & $(2)$ \\
& all workers & exclude cross-border commuters \\
\hline \multirow{2}{*}{ black } & $-0.0946^{* * *}$ & $-0.0995^{* * *}$ \\
license & $(0.0297)$ & $(0.0314)$ \\
& 0.0258 & 0.0152 \\
license $\times$ black & $(0.0216)$ & $(0.0240)$ \\
felony ban $\times$ BTB & -0.0122 & 0.00271 \\
felony ban $\times$ BTB $\times$ black & $(0.0645)$ & $(0.0709)$ \\
felony ban $\times$ nonBTB & -0.102 & -0.114 \\
felony ban $\times$ nonBTB black & $(0.0816)$ & $(0.0928)$ \\
& $\left(0.194^{*}\right.$ & $0.209^{*}$ \\
Constant & $-0.0485)$ & $(0.119)$ \\
& $(0.0402)$ & -0.0428 \\
& 0.0775 & $(0.0405)$ \\
Observations & $(0.118)$ & 0.0722 \\
R-squared & $1.316^{* * *}$ & $(0.125)$ \\
\hline \hline
\end{tabular}

Data Source: SIPP Panel 2014; American Bar Association Database. We use Panel 2014 to check the issue of cross-border commutes because Panel 2008 lacks this information.

Notes: Dependent variable is the log of hourly wage. The 'license' variable is based on the 50-50 rule (a state-specific 6 digit-level occupation requires a license if $50 \%$ or more respondents in that cell reported having a license in SIPP). 'Felony ban' indicator equals 1 only if 'license' equals 1. Ban-the-Box (BTB) states refer to state implemented statewide BTB law in the public or private sector. They include California, Colorado, Connecticut, DC, Hawaii, Massachusetts, Minnesota, and New Mexico. The sample is restricted to male workers who are white or black. Hispanics and workers of other races are excluded. All regressions include month, state, and 6-digit occupation fixed effects. Individual controls include a quadratic in age, education levels, union status, a government worker indicator, a self-employed indicator, a service worker indicator. In addition, we include indicators for 'certification' and 'license not required for jobs.' The sample is restricted to respondents aged 18-64 with hourly wages on the main job between $\$ 5$ and $\$ 100$. Observations with imputed wages and license status are dropped. All regressions are weighted by sampling weight. Standard errors are clustered at the state level. ***,**,* correspond to $1 \%, 5 \%, 10 \%$ significance level, respectively. 
Table B6: Results using individual self-reported licensing status

\begin{tabular}{|c|c|c|c|c|c|c|c|}
\hline & $(1)$ & $(2)$ & (3) & (4) & (5) & (6) & (7) \\
\hline black & $\begin{array}{c}-0.0988^{* * *} \\
(0.0173)\end{array}$ & $\begin{array}{l}-0.111^{* * *} \\
(0.0184)\end{array}$ & $\begin{array}{l}-0.110^{* * *} \\
(0.0185)\end{array}$ & $\begin{array}{l}-0.109^{* * *} \\
(0.0178)\end{array}$ & $\begin{array}{l}-0.110^{* * *} \\
(0.0199)\end{array}$ & $\begin{array}{l}-0.145^{* * *} \\
(0.0217)\end{array}$ & $\begin{array}{l}-0.111^{* * *} \\
(0.0204)\end{array}$ \\
\hline license & $\begin{array}{c}0.0517^{* * *} \\
(0.0135)\end{array}$ & $\begin{array}{l}0.0407^{* *} \\
(0.0157)\end{array}$ & $\begin{array}{l}0.0330^{*} \\
(0.0179)\end{array}$ & $\begin{array}{l}0.0341^{*} \\
(0.0177)\end{array}$ & $\begin{array}{l}0.00279 \\
(0.0218)\end{array}$ & $\begin{array}{l}0.00432 \\
(0.0215)\end{array}$ & $\begin{array}{l}0.00201 \\
(0.0217)\end{array}$ \\
\hline license $\times$ black & & $\begin{array}{l}0.115^{* *} \\
(0.0553)\end{array}$ & $\begin{array}{l}0.0882^{*} \\
(0.0505)\end{array}$ & $\begin{array}{l}0.0902^{*} \\
(0.0507)\end{array}$ & $\begin{array}{c}0.0880 \\
(0.0734)\end{array}$ & $\begin{array}{c}0.0830 \\
(0.0694)\end{array}$ & $\begin{array}{c}0.0895 \\
(0.0734)\end{array}$ \\
\hline felony ban $\times$ BTB & & & $\begin{array}{c}0.0394 \\
(0.0362)\end{array}$ & $\begin{array}{c}0.0391 \\
(0.0362)\end{array}$ & $\begin{array}{c}0.0404 \\
(0.0349)\end{array}$ & $\begin{array}{c}0.0414 \\
(0.0336)\end{array}$ & $\begin{array}{c}0.0394 \\
(0.0339)\end{array}$ \\
\hline felony ban $\times$ BTB $\times$ black & & & $\begin{array}{l}0.203^{* * *} \\
(0.0578)\end{array}$ & $\begin{array}{l}0.199^{* * *} \\
(0.0577)\end{array}$ & $\begin{array}{l}0.211^{* * *} \\
(0.0649)\end{array}$ & $\begin{array}{l}0.217^{* * *} \\
(0.0668)\end{array}$ & $\begin{array}{l}0.209^{* * *} \\
(0.0694)\end{array}$ \\
\hline felony ban $\times$ nonBTB & & & $\begin{array}{l}0.0295 \\
(0.0303)\end{array}$ & $\begin{array}{c}0.0310 \\
(0.0305)\end{array}$ & $\begin{array}{c}0.0285 \\
(0.0302)\end{array}$ & $\begin{array}{c}0.0295 \\
(0.0296)\end{array}$ & $\begin{array}{c}0.0323 \\
(0.0291)\end{array}$ \\
\hline felony ban $\times$ nonBTB $\times$ black & & & $\begin{array}{l}0.0377 \\
(0.100)\end{array}$ & $\begin{array}{l}0.0344 \\
(0.102)\end{array}$ & $\begin{array}{l}0.0292 \\
(0.102)\end{array}$ & $\begin{array}{l}0.0682 \\
(0.108)\end{array}$ & $\begin{array}{l}0.0443 \\
(0.105)\end{array}$ \\
\hline Constant & $\begin{array}{l}2.112^{* * *} \\
(0.0756)\end{array}$ & $\begin{array}{l}2.110^{* * *} \\
(0.0756)\end{array}$ & $\begin{array}{l}2.109^{* * * *} \\
(0.0760)\end{array}$ & $\begin{array}{l}2.111^{* * * *} \\
(0.0758)\end{array}$ & $\begin{array}{l}2.115^{* * * *} \\
(0.0761)\end{array}$ & $\begin{array}{l}2.097^{* * * *} \\
(0.0760)\end{array}$ & $\begin{array}{l}2.143^{* * *} \\
(0.0873)\end{array}$ \\
\hline Observations & 30,256 & 30,256 & 30,256 & 30,256 & 30,256 & 30,256 & 30,256 \\
\hline R-squared & 0.560 & 0.561 & 0.561 & 0.561 & 0.561 & 0.563 & 0.564 \\
\hline license reason (personal interest) & & & & $\mathrm{X}$ & $\mathrm{X}$ & $\mathrm{X}$ & $\mathrm{X}$ \\
\hline continuous edu & & & & & $X$ & $X$ & $X$ \\
\hline $\begin{array}{l}\text { advanced class } \\
\text { advanced class (higher-order residual) }\end{array}$ & & & & & & $x$ & $x$ \\
\hline
\end{tabular}

Data Source: Wave 13 of SIPP Panel 2008; American Bar Association Database.

Notes: Dependent variable is the log of hourly wage. Ban-the-Box (BTB) states refer to state implemented statewide BTB law in the public or private sector. They include California, Colorado, Connecticut, DC, Hawaii, Massachusetts, Minnesota, and New Mexico. The sample is restricted to male workers who are white or black. Hispanics and workers of other races are excluded.

All regressions include month, state, and 6-digit occupation fixed effects. Individual controls include a quadratic in age, education levels, union status, a government worker indicator, a self-employed indicator, a service worker indicator. In addition, we include indicators for 'certification', 'license not required for jobs.' The sample is restricted to respondents aged 18-64 with hourly wages on the main job between $\$ 5$ and $\$ 100$. Observations with imputed wages and license status are dropped. All regressions are weighted by sampling weight. Standard errors are clustered at the state level. ***, **, * correspond to $1 \%, 5 \%, 10 \%$ significance level, respectively. 
Table B7: Summary Statistics for SIPP and CPS Samples

\begin{tabular}{lcccc}
\hline \hline & \multicolumn{2}{c}{$(1)$} & \multicolumn{2}{c}{$(2)$} \\
& \multicolumn{2}{c}{ SIPP } & \multicolumn{2}{c}{ CPS } \\
& mean & sd & mean & sd \\
\hline wage & 25.07 & 15.46 & 26.72 & 15.43 \\
black & 0.125 & 0.331 & 0.137 & 0.343 \\
age & 41.23 & 12.24 & 41.76 & 12.17 \\
high school & 0.247 & 0.431 & 0.289 & 0.454 \\
some college & 0.360 & 0.480 & 0.282 & 0.450 \\
college & 0.237 & 0.425 & 0.259 & 0.438 \\
post-graduate & 0.117 & 0.322 & 0.128 & 0.335 \\
\hline Observations & 30,256 & \multicolumn{3}{c}{52,034} \\
\hline
\end{tabular}

This tables compare the key demographics among the men sample in the SIPP (Panel 2008) and the 2015 monthly CPS. The CPS sample also restrict to whites and non-Hispanic blacks with age between 18 and 64 and whose hourly wage is between $\$ 5$ and $\$ 100$. 